\title{
Volcanism above a subducted extinct spreading center: a reconnaissance study of the North Luzon Segment of the Taiwan-Luzon Volcanic Arc (Philippines)
}

\author{
Ulrich Knittel, ${ }^{\star} \dagger$ Alfonso G. Trudu, $\ddagger$ Walter Winter,§ T. F. Yang $\dagger \dagger$ and \\ Chris M. Gray $\uparrow$ \\ *Department of Geology, University of Melbourne, Parkville, Victoria 3052, Australia; $\ddagger$ Department \\ of Earth Sciences, Monash University, Clayton, Victoria 3168, Australia; §Institut für Mineralogie \\ und Lagerstättenlehre, Wüllnerstr. 2, D-5100 Aachen, Germany; +†Department of Geology, National \\ Taiwan University, 245 Choushan Road, Taipei 10770, Taiwan, Republic of China; and ๆDepartment \\ of Geology, La Trobe University, Bundoora, Victoria 3083, Australia
}

\begin{abstract}
The aseismic ridge system of the South China Sea, extinct since about $17 \mathrm{Ma}$, subducts below the central part of the Taiwan-Luzon volcanic arc, North Luzon Segment (NLS). The buoyancy of the relatively young and warm crust of the ridge system may be responsible for the high elevation of the NLS. Volcanism in this part of the arc is characterized by the eruption of small volumes of intermediate to felsic magma $\left(57-65 \% \mathrm{SiO}_{2}\right)$. The eruption products from the volcanic front in the central part of the Cordillera form a low-K, calc-alkaline suite, characterized by high $\mathrm{Sr}$ and low HREE and $\mathrm{Y}$ contents. Some workers consider these characteristics to be the geochemical fingerprints of magmas generated by slab-melting. However, model calculations require the amount of residual garnet in the source to be small $(\leqslant 10 \%)$, in contrast to experimental work that indicates high amounts of residual garnet $(\geqslant 30 \%)$. Alternatively, the melts may have been generated by melting of amphibolitic lower crust. The magmas erupted in the eastern and southern parts of the segment are calc-alkaline suites with moderate to high $\mathrm{K}$ contents and $\mathrm{Sr}$ and $\mathrm{Y}$ contents typical for arc suites. The small volume and evolved composition of the erupted magmas may be related to the uplift of the NLS with the crust acting as a density filter, which prevents more mafic magmas from reaching the surface.
\end{abstract}

\section{Introduction}

The subduction of spreading centers may affect magmatism of volcanic arcs in different ways. In some arcs, the impact of the ridge resulted in deep faulting, which provided pathways for the ascent of primitive magmas (e.g. Solomon Islands: Ramsay et al., 1984; Vanuatu: Barsdell and Berry, 1990). Where young ridges are subducted, the dip of the down-going plate may be reduced due to the buoyancy of the still warm crust. As a result, the mantle wedge between subducted slab and crust is shifted far inland, resulting in cessation of arc volcanism, because the subducted crust becomes dehydrated before reaching the mantle wedge (e.g. in the non-volcanic zone of the South American Andes; Mahlburg-Kay et al., 1988). Another consequence of the subduction of young oceanic lithosphere may be the melting of the subducted crust, a process recently investigated by Drummond and Defant (1990) and Defant and Drummond (1990).

The North Luzon Segment (NLS) of the TaiwanLuzon volcanic arc, which overlies the extinct spreading center of the South China Sea, offers an opportunity to study the magmatic response to subduction of a young ridge. In this contribution we: (1) review the tectonic

+ Present address: Institut für Mineralogie und Lagerstättenlehre, Wüllnerstr. 2, D-52056 Aachen, Germany. setting of late-Miocene to Quarternary volcanism in the NLS; (2) present new petrographic and geochemical data for igneous rocks from different localities along the NLS; and (3) discuss the petrogenesis of the volcanic rocks within their tectonic framework.

\section{Tectonic and Geological Setting}

The Luzon arc, formed in response to the subduction of the South China Sea along the Manila Trench, extends for about $900 \mathrm{~km}$ from eastern Taiwan to the island of Mindoro in the central Philippines. The arc is composed of five segments, characterized by distinct tectonic setting and magma chemistry (Defant et al., 1989). From north to south, these are: (1) the Taiwan Segment; (2) the Bashi Segment, which includes all the small islands located between Taiwan and Luzon and Cagua Volcano in northeastern Luzon (in contrast to Defant et al., 1989, we include the islands Lutao and Lanshu in this segment, because the magmas erupted resemble those of the southern islands in terms of geochemical and isotopic variability, cf. Chen et al., 1990; McDermott et al., 1993); (3) the North Luzon Segment, which extends along the Cordillera Central of northwestern Luzon as far south as the LingayenDingalan Fault; (4) the Bataan Segment; and (5) the Mindoro Segment. The last two are separated by the 


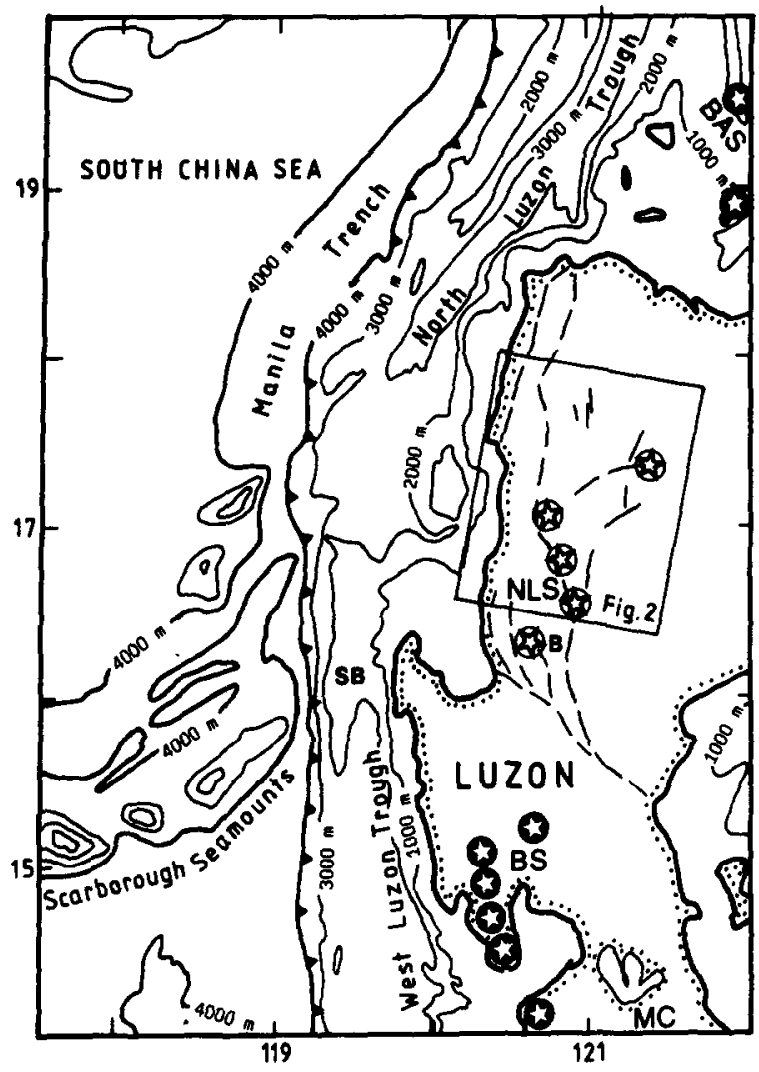

* stratovolcano cluster of volcanic domes

Fig. 1. Tectonic setting of the North Luzon segment (NLS) of the Taiwan-Luzon arc (modified after Lewis and Hayes, 1984; Pautot and Rangin, 1989; Ringenbach et al., 1990; Balce et al., 1980). The cluster of volcanic domes south of the area shown in Fig. 2 and labelled B is the Baguio District. The locations of the Bashi Segment (BAS), the Bataan Segment (BA) and the Macolod Corridor (MC) are indicated. SB is the Steward Bank.

Macolod Corridor, which Defant et al. (1988) and Förster et al. (1990) suggested to be a "pull-apart" zone (Fig. 1).

Convergence along the Manila Trench is thought to be roughly WSW-ENE (de Boer et al., 1980), i.e. subparallel to the strike of the Scarborough Seamount chain (Fig. 1), which is inferred to be the extinct spreading center of the South China Sea (e.g. Taylor and Hayes, 1983; Pautot et al., 1986). North of about $17.5^{\circ} \mathrm{N}$, the trench is about $45 \mathrm{~km}$ wide and narrows to the south to $10-15 \mathrm{~km}$, where the Scarborough Seamount chain is being subducted (Pautot and Rangin, 1989). As a consequence of the location of the spreading center at the southern end of the NLS, the subducting crust becomes progressively older towards the north (magnetic anomaly $5 e$ to anomaly 10 , i.e. 17-30 Ma; Taylor and Hayes, 1983).

East of the Manila Trench, and separated from it by an accretionary prism, the North Luzon Trough contains up to $4 \mathrm{~km}$ of sediment (Hayes and Lewis, 1984). Its southern end, the Steward Bank lies roughly along the strike of the Scarborough Seamount Chain. This complex is believed to be composed of a mixture of igneous and sedimentary rocks (Hayes and Lewis, 1984) and is interpreted to be a slice of the South China Sea spreading center accreted to the upper plate (Pautot and Rangin, 1989).
The Ilocos Basin lies east of the North Luzon Trough and is thought to be the northward extension of the Central Valley of Central Luzon (e.g. Hayes and Lewis, 1984), an older sedimentary basin, which probably overlies the northern extension of the Zambales Ophiolite (Hayes and Lewis, 1984). The same sedimentary sequences form the foothills of the Cordillera Central, which, in its core, is largely composed of Early Tertiary volcanic rocks that were intruded by large, composite batholiths during the Oligocene/early Miocene (e.g. Fernandez and Damasco, 1979; Balce et al., 1980; Metal Mining Agency of Japan, 1977, 1981). At least two major strike-slip fault systems (the Vigan-Aggao and Abra River Faults) cut the Cordillera into several longitudinal slices (Fig. 2; Ringenbach et al., 1990).

The NLS differs significantly from typical oceanic arcs and the other segments of the Taiwan-Luzon system by its high elevation with large areas lying at altitudes of $1200-2200 \mathrm{~m}$. Uplift occurred after the deposition of the Kennon limestone in Mid-Miocene time (Balce et al., 1980). Christian (1964), among others, argues for a period of significant uplift in the Pleistocene, based on the sedimentary record in the Cagayan Basin. High elevations are usually found in arcs colliding with crust of increased thickness, but the NLS is not such a collision zone. In this respect the NLS is similar to the South American Andes and a similar mechanism may be responsible for the uplift, i.e the subduction of young ( $<25$ m.y.) oceanic crust along the Manila Trench. Oceanic crust younger than about 25 m.y. is still warm, hence less dense, and capable to uplift the overlying crust-mantle wedge due to its buoyancy (Uyeda, 1982; Yang et al., 1992). Since the youngest parts of the South China Sea crust have been subducted below northern Luzon, the NLS experienced the most uplift (note that elevations $>2000 \mathrm{~m}$ occur only at $16^{\circ} 30^{\prime}-17^{\circ} 30^{\prime} \mathrm{N}$, more or less exactly east of the "collision zone"; sce Fig. 2 in Ringenbach et al., 1993).

\section{Volcanism in the North Luzon Segment}

There are few known preserved young volcanic landforms within the NLS, including three small craters in the Kalinga-Apayao Province (Alvir, 1956). However, Holocene volcanism is indicated by a ${ }^{14} \mathrm{C}$-age of 7800 years for an ignimbrite (Ringenbach et al., 1993). This may be due to either a lack of stratovolcanoes in this segment of the Taiwan-Luzon arc or to very rapid erosion resulting from the Pleistocene uplift of this mountain range.

Only a limited amount of work has been carried out on the magmatic rocks from the NLS, restricted mainly to the Baguio District located at the southern end of the NLS and some additional data for the Cervantes-Lepanto area (Balce, 1979; Shannon, 1979; Divis, 1983; Lo, 1981; Defant et al., 1990; Ringenbach et al., 1990). Unfortunately, Lo (1981) and Defant et al. (1990) do not provide any details about sampling localities, and thus, the geological context of their samples is uncertain.

The available geochemical data indicate compositional variety in the NLS with most published analyses falling into the field of common calc-alkaline rocks and few into the low-K field (Peccerillo and Taylor, 1976). Sr-isotopic 


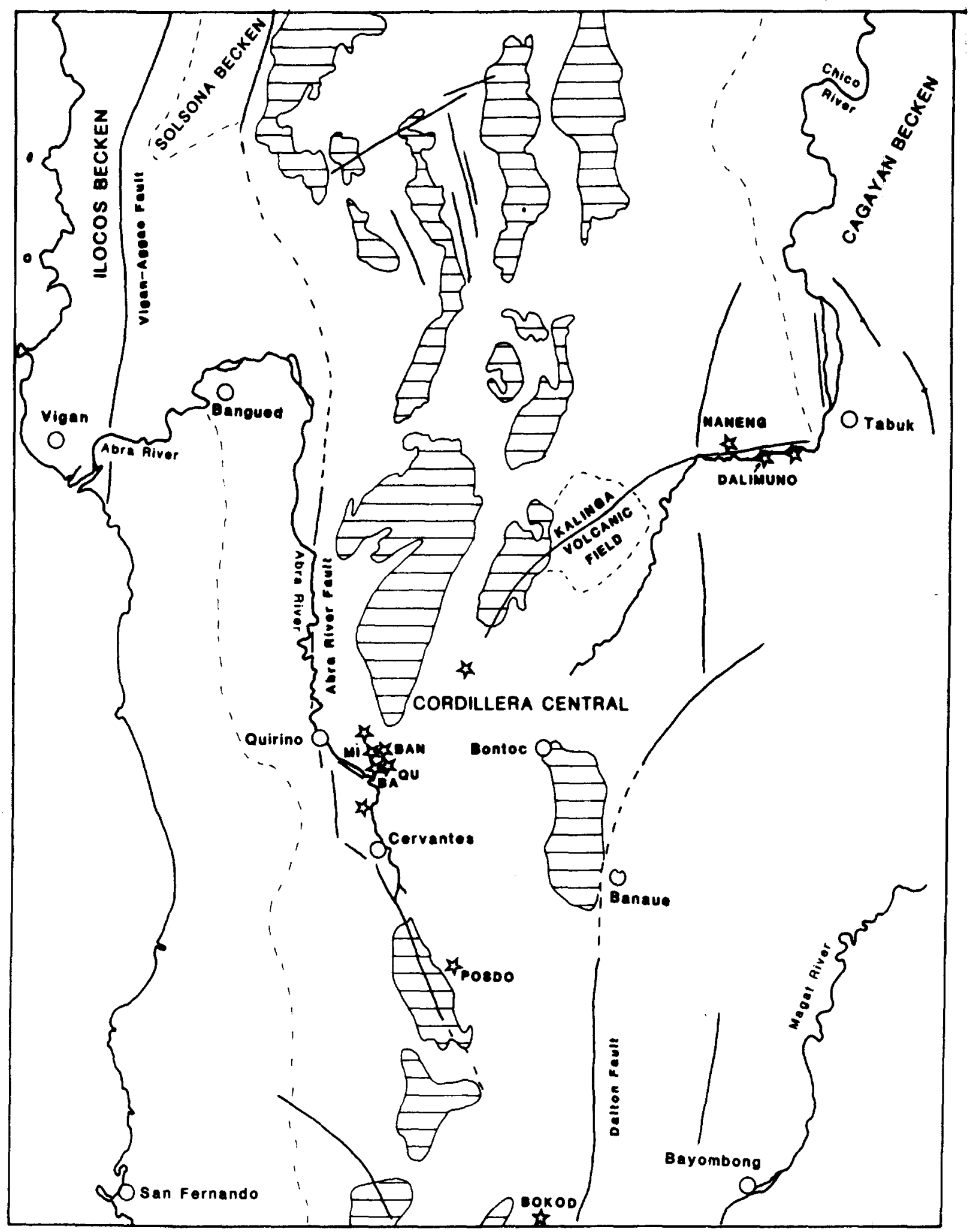

Fig. 2. Tectonic map of the central part of the North Luzon Segment based on a Landsat-photo (Metal Mining Agency of Japan, 1981; Ringenbach et al., 1990; Winter, unpublished data). Only those faults indicated on the maps of Mctal Mining Agency of Japan (1981) and Ringenbach et al. (1990) seen on the Landsat-photo are shown here. Stars are volcanic domes and plugs (MI = Minlawi Plug, BAN = Banawue Plug, BA = Batog $\mathrm{Knob}, \mathrm{QU}=$ Quinali dome). Ruled areas are outcrops of Oligocene plutons.

data for the Baguio area (0.7032-0.7037, Divis, 1983; Defant et al., 1990) indicate that ${ }^{87} \mathrm{Sr} /{ }^{86} \mathrm{Sr}$ ratios in the NLS are lower than in the southern segments of the Taiwan-Luzon arc and are in the same range as most volcanic rocks of the Taiwan Segment, older volcanics of the Bashi Segment (Calayan, Camiguin, Mt Cagua;
Chen et al., 1990; McDermott et al., 1993), Pliocene to Recent volcanic rocks from the Bicol arc in southern Luzon ${ }^{87} \mathrm{Sr}{ }^{86} \mathrm{Sr}$ : 0.7035-0.7040; Divis, 1980; KnittelWeber and Knittel, 1990) and pre-Miocene plutonic rocks from Luzon $\left({ }^{87} \mathrm{Sr}{ }^{86} \mathrm{Sr}: 0.7035-0.7041\right.$, Knittel and Defant, 1988; Winter et al., unpublished data). 


\section{Cervantes-Lepanto area}

The geology of the Cervantes-Lepanto area, located in the western part of the Cordillera Central, is dominated by the Cervantes Trough, developed east of the Abra River Fault, where it makes a sharp westward bent before returning to its "normal" $\mathrm{N}-\mathrm{S}$ direction (Ringenbach et al., 1990) (Fig. 2). The trough is thought to have formed in relation to movements along the Abra River Fault, which is considered to be the median branch of the northern horsetail-like ramification of the strikeslip Philippine Fault (Ringenbach et al., 1990). A thick volcaniclastic sequence, mildly folded and faulted, fills the trough.

Clusters of small volcanic edifices occur at the northeastern and southeastern ends of the trough (Fig. 2) in the Quirino and Lepanto areas. Other eruption centers thought to be scattered throughout the basin (Ringenbach et al., 1990) have subsequently been identified to consist of reworked material (Ringenbach et al., 1993, and written communication, 1992).

The northeastern eruption centers are located about $5-10 \mathrm{~km}$ east of the township Quirino (Ilocos Sur), at the northeastern margin of the trough along the Balasian River, a tributary of the Abra River. Four of the five dacitic plugs, having diameters of $500-1000 \mathrm{~m}$, were sampled: the Minlawi, Banawue, Batog and Mt Quinali Plugs.

The plugs intruded altered volcanic flows (predominantly amygdaloidal basalts and andesites) with locally intercalated sediments, considered to be part of the Eocene Licuan Group of Formation I (Metal Mining Agency of Japan, 1981). West of the intrusive bodies, towards the Abra River, unaltered volcaniclastic rocks crop out and represent the Miocene-Pleistocene basin fill of the Cervantes Trough.

No radiometric age determinations have been carried out on the plugs of the Quirino area. An andesite dike, exposed in the lower Balasian River and compositionally similar to the plugs (Table 1), has been dated at $9.8 \pm 2.0 \mathrm{Ma}$ (Metal Mining Agency of Japan, 1981). Ringenbach et al. (1990) give similar ages for several dikes in the area. Andesitic to dacitic clasts in monogenic conglomerates in the Cervantes Trough yield younger $\mathrm{K}-\mathrm{Ar}$ ages of 3.7-4.9 Ma (Ringenbach et al., 1990; Ringenbach, 1992), raising the possibility of a younger

Table 1. Chemical and Sr isotope composition of volcanic rocks from the Quirino and Lepanto areas (major elements in wt\%, trace elements in $\mathrm{ppm}$ )

\begin{tabular}{|c|c|c|c|c|c|c|c|c|c|c|c|}
\hline \multirow[b]{2}{*}{ Sample } & \multicolumn{5}{|c|}{ Quirino area } & \multicolumn{6}{|c|}{ Lepanto area } \\
\hline & $\begin{array}{l}\text { Batog } \\
\text { P1-76 }\end{array}$ & $\begin{array}{c}\text { Dyke } \\
\text { B 3350 }\end{array}$ & $\begin{array}{l}\text { Quinali } \\
\text { P1-77 }\end{array}$ & $\begin{array}{c}\text { Minlawi } \\
\text { P1-78 }\end{array}$ & $\begin{array}{c}\text { Banawue } \\
\text { P1-72 }\end{array}$ & TTP216 & TTP245D & $\begin{array}{c}\text { Posdo } \\
\text { TTP169 }\end{array}$ & TTP42 & TTP245H & $\begin{array}{c}\text { Tirad } \\
329\end{array}$ \\
\hline $\mathrm{SiO}_{2}$ & 57.99 & 60.08 & 61.33 & 61.66 & 64.72 & 57.01 & 61.62 & 62.65 & 62.50 & 63.83 & 62.06 \\
\hline $\mathrm{TiO}_{2}$ & 0.55 & 0.50 & 0.43 & 0.39 & 0.44 & 0.58 & 0.35 & 0.52 & 0.48 & 0.35 & 0.38 \\
\hline $\mathrm{Al}_{2} \mathrm{O}_{3}$ & 18.00 & 17.64 & 17.52 & 17.61 & 16.58 & 19.94 & 17.83 & 17.06 & 18.82 & 17.16 & 15.46 \\
\hline $\mathrm{Fe}_{2} \mathrm{O}_{3}$ & 6.41 & 2.76 & 5.12 & 4.39 & 4.38 & 6.23 & 3.73 & 4.94 & 4.97 & 4.06 & 5.43 \\
\hline $\mathrm{FeO}$ & - & 3.81 & - & - & - & - & - & - & - & - & - \\
\hline $\mathrm{MnO}$ & 0.15 & 0.17 & 0.32 & 0.12 & 0.06 & 0.13 & 0.10 & 0.07 & 0.12 & 0.11 & 0.02 \\
\hline $\mathrm{MgO}$ & 3.24 & 2.75 & 2.57 & 1.89 & 1.75 & 1.66 & 1.48 & 1.39 & 1.24 & 1.44 & 2.14 \\
\hline $\mathrm{CaO}$ & 7.40 & 7.02 & 6.89 & 6.05 & 4.71 & 4.23 & 6.11 & 4.96 & 6.16 & 5.84 & 5.03 \\
\hline $\mathrm{Na}_{2} \mathrm{O}$ & 3.48 & 3.35 & 3.73 & 3.71 & 4.01 & 2.93 & 4.05 & 3.55 & 4.17 & 3.64 & 4.39 \\
\hline $\mathrm{K}_{2} \mathrm{O}$ & 0.76 & 0.58 & 0.38 & 1.13 & 1.65 & 0.90 & 0.37 & 2.85 & 0.95 & 0.75 & 1.00 \\
\hline $\mathrm{P}_{2} \mathrm{O}_{5}$ & 0.18 & 0.21 & 0.15 & 0.16 & 0.22 & 0.19 & 0.13 & 0.29 & 0.16 & 0.11 & 0.10 \\
\hline Loss & 1.72 & 1.07 & 1.54 & 2.92 & 0.99 & 5.49 & 4.31 & 0.86 & 0.56 & 2.47 & 1.11 \\
\hline Total & 99.88 & 99.94 & 99.98 & 100.03 & 99.51 & 99.29 & 100.08 & 99.14 & 100.13 & 99.76 & 97.12 \\
\hline $\mathbf{R b}$ & 10 & n.a. & 4 & 26 & 24 & 7 & 8 & 78 & 20 & 14 & 25 \\
\hline $\mathrm{Sr}$ & 461 & n.a. & 579 & 716 & 590 & 436 & 518 & 612 & 589 & 509 & 410 \\
\hline $\mathrm{Ba}$ & 188 & n.a. & 216 & 582 & 527 & 529 & 140 & 536 & 293 & 225 & 306 \\
\hline Th & 1.76 & n.a. & 1.20 & 1.24 & 5.24 & 2.72 & 2.73 & n.d. & 1.72 & 2.05 & 1.69 \\
\hline $\mathrm{U}$ & 0.71 & n.a. & 0.48 & 0.60 & 0.76 & 0.68 & 1.16 & n.d. & 0.58 & 1.00 & 0.55 \\
\hline $\mathrm{Nb}$ & 3 & n.a. & 1 & 2 & 5 & 4 & 3 & 3 & 4 & 2 & 2 \\
\hline $\mathrm{Ta}$ & 0.13 & n.a. & 0.27 & 0.11 & 0.27 & 0.17 & 0.15 & n.d. & 0.12 & 0.14 & 0.22 \\
\hline $\mathrm{Zr}$ & 70 & n.a. & 86 & 71 & 100 & 92 & 78 & 98 & 78 & 73 & 64 \\
\hline $\mathrm{Hf}$ & 2.27 & n.a. & 2.39 & 1.73 & 2.43 & 2.73 & 3.09 & n.d. & 2.50 & 2.19 & 2.01 \\
\hline$Y$ & 11 & n.a. & 12 & 12 & 13 & 8 & 12 & 14 & 12 & 10 & 7 \\
\hline $\mathrm{Ni}$ & 11 & n.a. & 11 & 7 & 5 & 8 & 10 & 15 & 19 & 7 & 13 \\
\hline $\mathrm{Cr}$ & 12 & n.a. & 31 & 17 & 15 & 10 & 2 & 7 & 17 & 12 & 16 \\
\hline $\mathrm{La}$ & 10.4 & n.a. & 7.87 & 7.90 & 24.4 & 10.6 & 10.7 & n.d. & 8.22 & 8.50 & 6.10 \\
\hline $\mathrm{Ce}$ & 19.0 & n.a. & 15.6 & 15.8 & 40.7 & 23.0 & 23.3 & n.d. & 16.8 & 17.8 & 12.0 \\
\hline $\mathrm{Nd}$ & 11.2 & n.a. & 10.0 & 9.69 & 18.9 & 13.1 & 11.6 & n.d. & 9.57 & 10.2 & 6.99 \\
\hline $\mathrm{Sm}$ & 2.39 & n.a. & 2.19 & 2.27 & 3.34 & 2.81 & 2.50 & n.d. & 2.31 & 2.33 & 1.61 \\
\hline $\mathrm{Eu}$ & 0.81 & n.a. & 0.73 & 0.68 & 0.76 & 0.81 & 0.79 & n.d. & 0.68 & 0.63 & 0.48 \\
\hline $\mathrm{Tb}$ & 0.56 & n.a. & 0.45 & 0.48 & 0.62 & 0.42 & 0.42 & n.d. & 0.35 & 0.36 & 0.32 \\
\hline $\mathrm{Yb}$ & 1.48 & n.a. & 1.69 & 1.49 & 1.33 & 1.14 & 1.21 & n.d. & 1.28 & 1.06 & 0.85 \\
\hline $\mathrm{Lu}$ & 0.23 & n.a. & 0.25 & 0.22 & 0.22 & 0.18 & 0.19 & n.d. & 0.19 & 0.17 & 0.14 \\
\hline${ }^{87} \mathrm{Sr} /{ }^{86} \mathrm{Sr}$ & 0.70357 & n.a. & 0.70354 & 0.70382 & 0.70363 & 0.70372 & 0.70377 & n.d. & n.d. & n.d. & n.d. \\
\hline
\end{tabular}

n.a. $=$ not available, n.d. $=$ not determined. Analysis B3350 is from Metal Mining Agency of Japan (1981), the K-Ar age of the sample is $9.8 \pm 2.0 \mathrm{Ma}$. ${ }^{87} \mathrm{Sr}{ }^{86} \mathrm{Sr}$ ratios have in-run statistical errors of $\pm 0.00002-0.00003$ and are considered to be accurate to \pm 0.00005 relative to NBS SRM $987^{87} \mathrm{Sr} /{ }^{86} \mathrm{Sr}=0.71025$ based on duplicate analyses. 
age for the main phase of volcanism in this area. On the other hand, the younger "ages" may be due to argon-losses in the reworked material.

The plugs are composed of porphyritic amphibole dacites. The Banawue Intrusion and Batog Plug are composed to very similar dacites, as are the Mt Quinali and the Minlawi Plug. The former contain few $(<15 \%)$ phenocrysts of plagioclase containing ubiquitous glass inclusions, and phenocrysts of amphibole in a matrix of tiny, box-shaped plagioclase crystals, magnetite and glass. Phenocrysts in Mt Quinali and Minlawi dacites are more abundant $(>35 \%)$ and larger (often more than $1 \mathrm{~mm}$ across), and plagioclase only rarely contains glass inclusions. In addition, the samples contain quartz phenocrysts with embayments.

The Lepanto area, Benguet Province, is located at the southeastern end of the Cervantes Trough (Fig. 2). The stratigraphy of the area (Gonzales, 1956; Sillitoe and Angeles, 1985; Garcia, 1990) consists of a lowermost unit, the Lepanto Metavolcanics, unconformably overlain by the Balili Sequence. The Lepanto Metavolcanics, possibly of late Cretaceous age (Fernandez and Pulanco, 1967), are composed of massive basalts and some evolved rocks, intercalated with minor turbidites and cut by mafic dikes; they have been metamorphosed to greenschist facies and are weakly deformed. Recently, Maleterre et al. (1988) suggested that this unit is part of an ophiolite underlying the Cordillera.

This sequence is intruded by the Bagon Intrusion (Knittel et al., 1990), a composite batholith radiometrically dated at $12-13 \mathrm{Ma}$ by Sillitoe and Angeles (1985), while Ringenbach et al. (1990) cite an unpublished date of $24 \mathrm{Ma}$. Work in progress by Winter suggests that the Bagon intrusive complex is part of the Oligocene to Early Miocene(?) suite of batholiths intruding the axis of the Cordillera Central range. The Bagon Intrusion consists mainly of quartz diorite with minor gabbroic, dioritic and granodioritic phases.

The mid-Miocene Balili Sequence is subdivided into two units (Baker, 1983): the Lower Clastic Unit consists of conglomerates with intercalated silt- and sandstone horizons, and the Upper Volcaniclastic Unit is composed of andesitic lavas and volcaniclastic rocks.

Small quartz diorite porphyry stocks intrude the Balili Sequence; one of them, the Tirad Stock (sample 329), located in the south of the Lepanto area, is spatially and genetically associated with the porphyry $\mathrm{Cu}-\mathrm{Au}$ mineralization of the Tirad prospect (Sillitoe and Angeles, 1985; Trudu, 1992). A K-Ar age of $3.5 \pm 0.9 \mathrm{Ma}$ from sericite associated with this mineralization is reported by Sillitoe and Angeles (1985). Another small quartz diorite porphyry stock underlies the epithermal $\mathrm{Au}-\mathrm{Cu}-\mathrm{As}$ deposit of Lepanto (Sillitoe, 1983). Emplacement of the stocks was followed by a series of phreatomagmatic explosions which produced diatreme/maar complexes $(2.9 \pm 0.4 \mathrm{Ma}$ from $\mathrm{K}-\mathrm{Ar}$ dating reported by Sillitoe and Angeles, 1985). One of them, named Posdo Diatreme complex by Trudu (1992), is described in some detail by Sillitoe and Angeles (1985). It consists of peripheral tuffs and breccias of dacitic composition and of a central subvolcanic dacitic dome. This complex postdates the Tirad mineralization and was not affected by hypogene alteration. The latest event may have been volcanism at $\mathrm{Mt}$ Tayebo, located south of Lepanto, which produced ash dated at $0.9 \pm 0.2 \mathrm{Ma}$ and 7700 year b.p. (Ringenbach, 1992).
Our samples of the Posdo Diatreme complex contain plagioclase, quartz and hornblende phenocrysts. Plagioclase phenocrysts are tabular, show oscillatory zoning, and have a zone rich in glass-inclusions near the margins. Quartz phenocrysts are rounded and show embayments. Amphibole phenocrysts are characterized by brown pleochroism. The groundmass ranges from a microcrystalline intergrowth of plagioclase and quartz to glass. Crystalrich and crystal-poor tuffs are recognized; their phenocryst assemblage differs from that of Posdo dacite described above in: (1) pleochroism of the hornblende (green-yellow in the tuffs and brown-pale yellow in the dacite); (2) higher contents of quartz and lower contents of plagioclase; and (3) the occurrence of rare deformed biotite. The groundmass of the tuff is composed of devitrified glass and a microcrystalline intergrowth of quartz and plagioclase. Lithic fragments are more abundant in the crystal-poor than in the crystal-rich tuff.

The Tirad Stock is not exposed but has been intersected by drill cores at depths ranging from 250 to $500 \mathrm{~m}$ below the surface during the exploration of the Tirad porphyry $\mathrm{Cu}-\mathrm{Au}$ mineralization. It is about $1000 \mathrm{~m}$ long and $500 \mathrm{~m}$ wide with steeply dipping sides. The subvolcanic rocks are composed of phenocrystic quartz, plagioclase, hornblende and biotite set in a groundmass of quartz with minor plagioclase. Similar porphyry-Cu mineralization occurs north of the Tirad prospect (Sillitoe, 1983; Conception and Cinco, 1989).

The samples analyzed for this study are fresh or, at most, very weakly altered (minor chlorite \pm epidote), as in the case of the Tirad Stock and the tuff of the Balili Formation.

\section{The Tabuk area}

The Tabuk area, Kalinga-Apayao Province, is located along the Chico River about $5-13 \mathrm{~km}$ east of the township of Tabuk. Three small intrusions occur along the Chico River Valley: these are, from east to west, the Naneng, Dalimuno and Mambucayan intrusions (Fig. 2). The largest of these, the Naneng intrusion, has a diameter of about $3000 \mathrm{~m}$ and is associated with a group of radial tension faults (Durkee and Pederson, 1961). The plugs intruded the turbidites of the Late Miocene to Pliocene Cabagan Formation (Caagusan, 1980) [the Cabagan Formation corresponds to the Buluan Formation of the Mabaca River Group of Durkee and Pederson (1961), the different names having been introduced by different oil companies working in the same general area (Christian, 1964)]. In the area between the Naneng and Dalimuno intrusions the sediments comprise siltstones with $\mathrm{cm}$ to $\mathrm{dm}$ thick intercalations of fine to medium grained impure sandstones. The detrital components of the sandstone (feldspars, quartz, rock fragments and opaque minerals) are subangular to angular, suggesting short transport distances. The siltstones are characterized by clay-rich, cross-laminated compositions.

The plugs are composed of porphyritic dacite and andesite (Table 2) with plagioclase and amphibole phenocrysts. Plagioclase phenocrysts usually contain zones or cores with glass patches. All samples are holocrystalline. Close to the contacts, the rocks are fine grained.

While Durkee and Pederson (1961) observed no particular relationship between the intrusions and adjacent structural elements, it appears from maps published by the Philippine Bureau of Mines (1974) and Caagusan 
Table 2. Chemical and $\mathrm{Sr}$ isotope composition of volcanic and sedimentary rocks from the Tabuk and Bokod areas (major elements in wt\%, trace elements in ppm)

\begin{tabular}{|c|c|c|c|c|c|c|c|c|c|c|}
\hline $\begin{array}{l}\text { Area } \\
\text { Subgroup } \\
\text { Sample }\end{array}$ & $\begin{array}{c}\text { Dalimuno } \\
\text { TBK1 }\end{array}$ & TBK2 & $\begin{array}{l}\text { Tabuk area } \\
\text { TBK } \\
\text { TBK4 }\end{array}$ & $\begin{array}{l}\text { Graywacke } \\
\text { TBK3sa }\end{array}$ & $\begin{array}{c}\text { Shale } \\
\text { TBK3sh }\end{array}$ & BOK 10 & $\begin{array}{l}\text { Bokod area } \\
\text { K152 }\end{array}$ & K149 & B251 & $\begin{array}{c}\text { Baguio } \\
\text { Black Mtn } \\
\text { P1-71 }\end{array}$ \\
\hline $\begin{array}{l}\mathrm{SiO}_{2} \\
\mathrm{TiO}_{2} \\
\mathrm{Al}_{2} \mathrm{O}_{3} \\
\mathrm{Fe}_{2} \mathrm{O}_{3} \\
\mathrm{FeO} \\
\mathrm{MnO} \\
\mathrm{MgO} \\
\mathrm{CaO} \\
\mathrm{Na}_{2} \mathrm{O} \\
\mathrm{K}_{2} \mathrm{O} \\
\mathrm{P}_{2} \mathrm{O}_{5} \\
\text { Loss }\end{array}$ & $\begin{array}{c}63.09 \\
0.39 \\
16.66 \\
3.88 \\
\text { n.d. } \\
0.10 \\
1.60 \\
5.20 \\
3.82 \\
1.78 \\
0.12 \\
3.28\end{array}$ & $\begin{array}{c}64.14 \\
0.40 \\
16.83 \\
3.79 \\
\text { n.d. } \\
0.11 \\
1.76 \\
4.80 \\
4.16 \\
1.82 \\
0.14 \\
1.97\end{array}$ & $\begin{array}{c}58.16 \\
0.54 \\
18.91 \\
5.67 \\
\text { n.d. } \\
0.18 \\
1.99 \\
7.32 \\
3.50 \\
1.42 \\
0.27 \\
2.38\end{array}$ & $\begin{array}{c}48.84 \\
0.69 \\
16.69 \\
5.85 \\
\text { n.d. } \\
0.10 \\
2.65 \\
8.48 \\
2.98 \\
1.55 \\
0.20 \\
11.40\end{array}$ & $\begin{array}{c}53.90 \\
0.74 \\
18.46 \\
8.83 \\
\text { n.d. } \\
0.10 \\
4.56 \\
1.79 \\
3.35 \\
1.45 \\
0.21 \\
6.78\end{array}$ & $\begin{array}{c}58.10 \\
0.57 \\
17.27 \\
6.00 \\
\text { n.d. } \\
0.11 \\
2.38 \\
5.88 \\
4.14 \\
2.31 \\
0.30 \\
2.07\end{array}$ & $\begin{array}{r}58.66 \\
0.59 \\
17.79 \\
2.39 \\
3.81 \\
0.13 \\
2.66 \\
5.37 \\
4.61 \\
2.26 \\
0.26 \\
0.74\end{array}$ & $\begin{array}{r}59.29 \\
0.52 \\
17.79 \\
2.11 \\
3.77 \\
0.14 \\
2.52 \\
4.56 \\
4.70 \\
2.17 \\
0.26 \\
1.41\end{array}$ & $\begin{array}{r}63.11 \\
0.44 \\
16.83 \\
2.43 \\
2.55 \\
0.09 \\
2.01 \\
2.89 \\
4.67 \\
2.10 \\
0.19 \\
2.36\end{array}$ & \begin{tabular}{|c}
55.87 \\
0.74 \\
16.44 \\
7.07 \\
n.d. \\
0.14 \\
4.82 \\
8.17 \\
3.29 \\
1.41 \\
0.17 \\
0.33
\end{tabular} \\
\hline Total & 99.92 & 99.92 & 100.34 & 99.43 & 100.17 & 99.13 & 99.27 & 99.24 & 99.67 & 98.45 \\
\hline $\begin{array}{l}\mathrm{Rb} \\
\mathrm{Sr} \\
\mathrm{Ba} \\
\mathrm{Th}{ }^{*} \\
\mathrm{U} \\
\mathrm{Nb} \\
\mathrm{Ta} \\
\mathrm{Zr} \\
\mathrm{Hf} \\
\mathrm{Y} \\
\mathrm{Ni} \\
\mathrm{Cr} \\
\mathrm{La} \\
\mathrm{Ce} \\
\mathrm{Nd} \\
\mathrm{Sm} \\
\mathrm{Eu} \\
\mathrm{Tb} \\
\mathrm{Yb} \\
\mathrm{Lu}\end{array}$ & $\begin{array}{c}48 \\
639 \\
599 \\
6.32 \\
1.60 \\
9 \\
0.64 \\
132 \\
3.1 \\
15 \\
7 \\
18 \\
23.6 \\
40.5 \\
18.0 \\
3.21 \\
0.75 \\
0.56 \\
1.59 \\
0.24\end{array}$ & $\begin{array}{c}54 \\
562 \\
610 \\
6.18 \\
1.60 \\
8 \\
0.63 \\
134 \\
3.18 \\
16 \\
7 \\
14 \\
24.7 \\
46.6 \\
17.1 \\
3.14 \\
0.79 \\
0.59 \\
1.55 \\
0.25\end{array}$ & $\begin{array}{c}33 \\
590 \\
354 \\
0 \\
\text { n.d. } \\
7 \\
\text { n.d. } \\
130 \\
\text { n.d. } \\
19 \\
8 \\
9 \\
\text { n.d. } \\
\text { n.d. } \\
\text { n.d. } \\
\text { n.d. } \\
\text { n.d. } \\
\text { n.d. } \\
\text { n.d. } \\
\text { n.d. }\end{array}$ & $\begin{array}{c}35 \\
884 \\
168 \\
0 \\
\text { n.d. } \\
2 \\
\text { n.d. } \\
70 \\
\text { n.d. } \\
15 \\
28 \\
98 \\
\text { n.d. } \\
\text { n.d. } \\
\text { n.d. } \\
\text { n.d. } \\
\text { n.d. } \\
\text { n.d. } \\
\text { n.d. } \\
\text { n.d. }\end{array}$ & $\begin{array}{c}34 \\
316 \\
106 \\
5 \\
\text { n.d. } \\
2 \\
\text { n.d. } \\
82 \\
\text { n.d. } \\
12 \\
20 \\
57 \\
\text { n.d. } \\
\text { n.d. } \\
\text { n.d. } \\
\text { n.d. } \\
\text { n.d. } \\
\text { n.d. } \\
\text { n.d. } \\
\text { n.d. }\end{array}$ & $\begin{array}{c}44 \\
1010 \\
564 \\
4.55 \\
1.24 \\
3 \\
0.19 \\
134 \\
3.47 \\
17 \\
10 \\
21 \\
20.8 \\
41.6 \\
23.4 \\
4.55 \\
1.19 \\
0.76 \\
1.92 \\
0.28\end{array}$ & $\begin{array}{l}\text { n.a. } \\
\text { n.a. } \\
\text { n.a. } \\
\text { n.a. } \\
\text { n.a. } \\
\text { n.a. } \\
\text { n.a. } \\
\text { n.a. } \\
\text { n.a. } \\
\text { n.a. } \\
\text { n.a. } \\
\text { n.a. } \\
\text { n.a. } \\
\text { n.a. } \\
\text { n.a. } \\
\text { n.a. } \\
\text { n.a. } \\
\text { n.a. } \\
\text { n.a. } \\
\text { n.a. }\end{array}$ & $\begin{array}{l}\text { n.a. } \\
\text { n.a. } \\
\text { n.a. } \\
\text { n.a. } \\
\text { n.a. } \\
\text { n.a. } \\
\text { n.a. } \\
\text { n.a. } \\
\text { n.a. } \\
\text { n.a. } \\
\text { n.a. } \\
\text { n.a. } \\
\text { n.a. } \\
\text { n.a. } \\
\text { n.a. } \\
\text { n.a. } \\
\text { n.a. } \\
\text { n.a. } \\
\text { n.a. } \\
\text { n.a. }\end{array}$ & $\begin{array}{l}\text { n.a. } \\
\text { n.a. } \\
\text { n.a. } \\
\text { n.a. } \\
\text { n.a. } \\
\text { n.a. } \\
\text { n.a. } \\
\text { n.a. } \\
\text { n.a. } \\
\text { n.a. } \\
\text { n.a. } \\
\text { n.a. } \\
\text { n.a. } \\
\text { n.a. } \\
\text { n.a. } \\
\text { n.a. } \\
\text { n.a. } \\
\text { n.a. } \\
\text { n.a. } \\
\text { n.a. }\end{array}$ & $\begin{array}{c}32 \\
429 \\
235 \\
\text { n.d. } \\
\text { n.d. } \\
4 \\
\text { n.d. } \\
96 \\
\text { n.d. } \\
19 \\
19 \\
\text { n.d. } \\
\text { n.d. } \\
\text { n.d. } \\
\text { n.d. } \\
\text { n.d. } \\
\text { n.d. } \\
\text { n.d. } \\
\text { n.d. } \\
\text { n.d. }\end{array}$ \\
\hline${ }^{87} \mathrm{Sr} /{ }^{86} \mathrm{Sr}$ & n.d. & 0.70413 & 0.70396 & 0.70545 & 0.70614 & 0.70362 & n.a. & n.a. & n.a. & 0.70372 \\
\hline
\end{tabular}

n.d. = not determined, n.a. = not available. ${ }^{*}$ INNA data for TBK1, TBK2, BOK10. Analyses K152, K149, B251 are from Metal Mining Agency of Japan (1977). Sample P1-71 was analyzed in Aachen by Winter and the Sr isotopic composition was determined by Albrecht in Albuquerque. ${ }^{87} \mathrm{Sr} /{ }^{86} \mathrm{Sr}$ ratios have in-run statistical errors of $\pm 0.00002-0.00003$ and are considered to be accurate to \pm 0.00005 relative to NBS SRM $987^{87} \mathrm{Sr} /{ }^{86} \mathrm{Sr}=0.71025$ based on duplicate analyses.

(1980) that they actually intruded the Upper Chico River Fault (Fig. 2), which displaces the N-S running fault at the western margin of the Cagayan Basin (Santiago and Chico River Faults) about $10 \mathrm{~km}$ in a left-lateral sense. The displacement has affected the Miocene to Pliocene Cabagan Formation, but has left Pleistocene gravels undisturbed, suggesting a pre-Pleistocene age for the fault (Caagusan, 1980) and a post-Pleistocene age for the small plugs.

About $25 \mathrm{~km}$ west of the Naneng Plug and probably still on the trace of the Upper Chico River Fault (which may be traced on a Landset-photo into the Quirino area) the Batong Buhay porphyry-Cu deposit lies approximately in the center of a $12 \times 10 \mathrm{~km}$ wide volcanic field (Metal Mining Agency of Japan, 1981). The cluster of volcanic vents described by Alvir (1956) lies south of Batong Buhay in the center of that field and may be the source of the volcanic rocks. Durkee and Pederson (1961) refer to the volcanic deposits as Awidon Mesa Formation, which they describe as being "composed of welded tuffs and tuffaceous sediments of a dacitic type ... characterized by the presence of bipyramidal quartz phenocrysts (generally less than 5\%) and euhedra of hornblende and sodic feldspar" (p. 159). They found that the volcanic deposits form a valley-filling deposit which attains a maximum thickness of at least $300 \mathrm{~m}$. West of the volcanic field a major pluton of the Oligocene to early Miocene suite of calc-alkaline batholiths is exposed (Metal Mining Agency of Japan, 1981).

\section{The Bokod area}

Very little is known about the local geology of the Bokod area, Benguet Province, located about $25 \mathrm{~km}$ ENE of the Baguio area (Figs 1 and 2), except for unpublished data by the Benguet Corp., which explored the Tawi-Tawi porphyry-Cu-Au prospect from 1969 until 1975, and a few chemical analyses and $\mathrm{K}-\mathrm{Ar}$ data from the Metal Mining Agency (1977). The most important geological feature of the area is the occurrence of one large and at least two smaller diorite porphyry stocks, the largest of which extends $5 \mathrm{~km} \mathrm{NS}$ and $2 \mathrm{~km}$ EW and hosts several porphyry copper ore bodies. 
The Bokod area is underlain by metamorphosed sedimentary and volcanic rocks (pre-Cretaceous?) overlain by unmetamorphosed volcanic units (Oligocene?). These rocks were intruded by the mineralized diorite porphyries and by hornblende diorite porphyry dikes, which postdate the mineralization. The pluton is estimated to have been emplaced at about 3-6 Ma, based on K-Ar data (Metal Mining Agency of Japan, 1977). Two major faults intersect the area: one trends north-south and defines the contact between the diorite and the unmetamorphosed volcanic units.

Metal Mining Agency of Japan (1977) has distinguished two phases of quartz diorite in the main stock: one characterized by abundant quartz phenocrysts and the other by few or no quartz phenocrysts. The one sample studied by us is very similar in major element composition to several samples analyzed by Metal Mining Agency of Japan (1977) and is considered to be representative of the plutonic units of the area (Table 2). It is a porphyritic microdiorite with large phenocrysts of plagioclase $(<2 \mathrm{~mm})$, amphibole $(<1 \mathrm{~mm})$, magnetite, and a few biotite crystals, which reflect the high potassium content of the rock.

\section{The Baguio district}

The Baguio district is located at the southern end of the Cordillera Central (Fig. 1). The geology of the area has been documented in several studies (Fernandez and Damasco, 1979; Balce et al., 1980; United Nations, 1987), but many important aspects are still unclear or contentious, e.g. the distribution and ages of the various units.

The eastern part of the area is underlain by several large plutons which form a composite batholith. There is no agreement on the age of this complex. $\mathrm{K}-\mathrm{Ar}$ data suggest ages of 12-18 Ma (Wolfe, 1981), but Balce et al. (1980) maintain, on the basis of geological mapping, that it is older than the Miocene Zigzag Formation. This discrepancy is probably due to the continued magmatic and hydrothermal activity in this area, which resulted in a resetting of the radiometric clocks. Recently, part of the plutonic complex has been re-interpreted as part of an ophiolite complex (United Nations, 1987).

To the west of the batholith several smaller plutons and dikes intrude the younger sedimentary formations, several of which have associated porphyry- $\mathrm{Cu}$ mineralization (e.g. Bryner, 1969; United Nations, 1987). The stocks appear to be younger than $15 \mathrm{Ma}$ (Wolfe, 1981). Though some data are available for these rocks, we do not discuss them in any detail, because neither the locations nor age relationships of most samples are known. In Table 2 we provide a new chemical analysis and $\mathrm{Sr}$ isotope determination for one of the young plugs, the Black Mountain complex (United Nations, 1987).

\section{Analytical Methods}

We have analyzed the samples for major, minor and trace elements by a low dilution XRF method (Thomas and Haukka, 1978). REE, Ta, U, Th and Hf concentrations were determined at the National Taiwan University (Taipai) by neutron activation analysis. Mineral compositions were determined in wavelength dispersive mode with a Cameca SX 50 electron microprobe using mineral and metal oxide standards and correction procedures given by Pouchou and Pichoir (1984). Sr isotope analyses were carried out at La Trobe University following the procedures described by Gray (1987), except that the analyses were done on unspiked samples.

\section{Bulk Rock Geochemistry}

The new analytical data are given in Tables 1 and 2 , which also include several analyses from the literature. All samples have similar $\mathrm{FeO}^{*} / \mathrm{MgO}$ ratios and thus form a calc-alkaline suite as defined by Miyashiro (1974, see Fig. 3a). The samples from the Posdo complex and the Quirino area (with the exception of Banawue sample P1-72 and sample TTP169 from the Posdo complex, characterized by unusually high $\mathrm{K}_{2} \mathrm{O}, \mathrm{Rb}, \mathrm{Sr}, \mathrm{Ba}, \mathrm{Y}$ and $\mathrm{Zr}$ contents, Table 1) fall into the field of low-K suites (Peccerillo and Taylor, 1976). The clasts from the Cervantes Trough (Ringenbach et al., 1990, 1993) appear to be slightly enriched in $\mathrm{K}_{2} \mathrm{O}$ and related trace elements (Ringenbach et al., 1990) and fall into the field of "normal" calc-alkaline suites. The Tabuk and the Banawue samples fall into the same field, while the Bokod samples straddle the boundary to the high-K suites (Fig. 3b). The low-K samples from the Posdo and Quirino areas show considerable scatter, in contrast to the often quasi-linear oxide- $\mathrm{SiO}_{2}$ relationships seen in many volcanic suites from destructive plate boundaries (here illustrated by the low-K suite of Mt Natib; Defant, 1985).

The volcanic rocks from the Quirino area and Posdo complex are notable for their low abundances in $\mathrm{K}_{2} \mathrm{O}$, $\mathrm{Rb}, \mathrm{Y}$ and $\mathrm{Zr}$. This is illustrated in Fig. 4, which compares the $\mathrm{Rb}$ and $\mathrm{Y}$ contents of these rocks with the low-K calc-alkaline suite of the Natib volcano in the Bataan Segment (cf. deBoer et al., 1980; Defant, 1985) and the low-K lavas of the Coastal Range of Taiwan

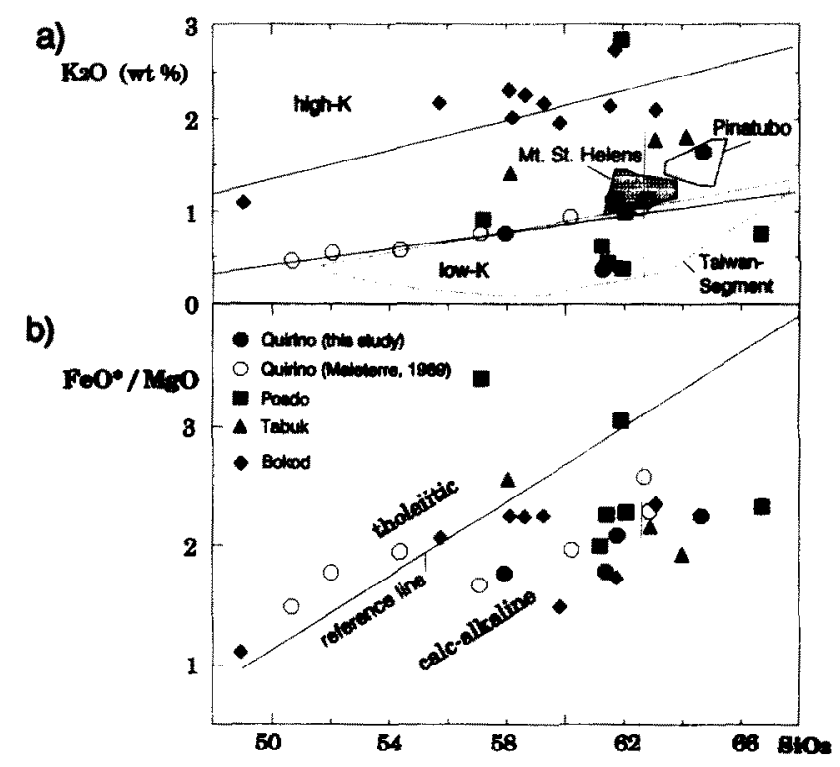

Fig. 3. (a) $\mathrm{K}_{2} \mathrm{O}$ vs $\mathrm{SiO}_{2}$ and (b) $\mathrm{FeO}^{*} / \mathrm{MgO}$ vs $\mathrm{SiO}_{2}$ for Late Miocene volcanic rocks from the Northern Luzon Segment. Boundary lines are from Peccerillo and Taylor (1976) and Miyashiro (1974), respectively. Data are from Tables 1 and 2, Maleterre, et al. (1988) and Ringenbach et al. (1990). Fields for Mt St Helens (Smith and Leeman, 1987) and Pinatubo dacites (Bernard et al., in press) are shown for comparison. 


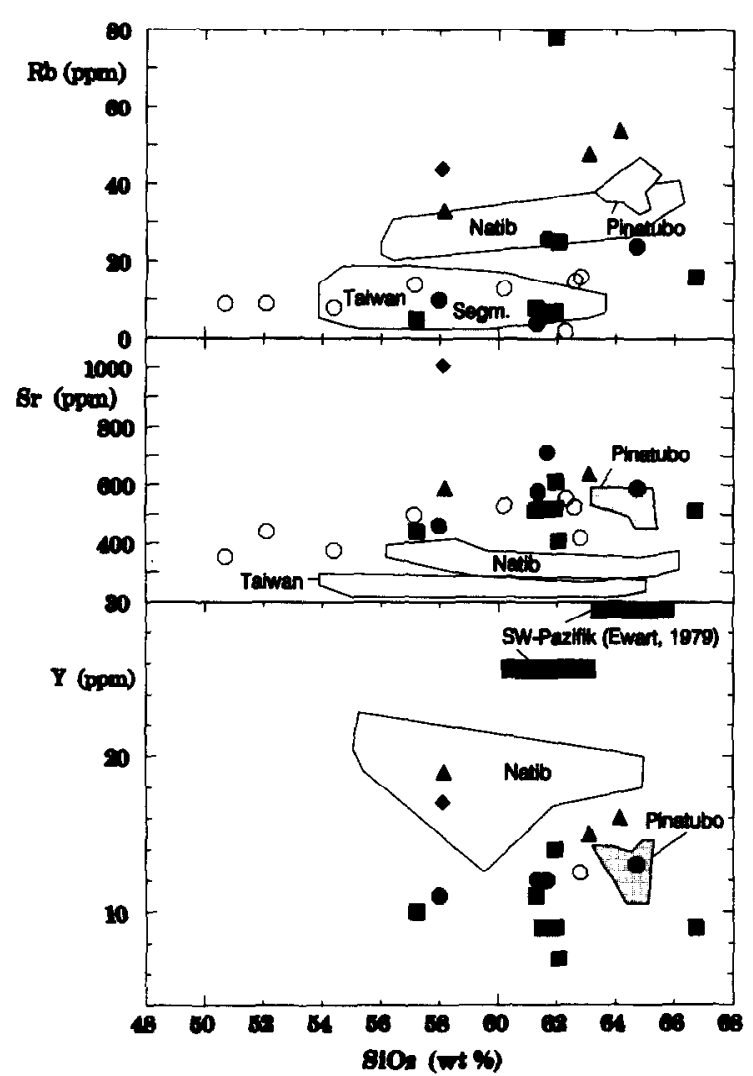

Fig. 4. Rb, Sr and $\mathrm{Y}$ contents of Late-Miocene rocks from the Northern Luzon Segment as compared to the low-K series of Natib in the Bataan Segment (data from Defant, 1985) and the low-K volcanics from the Coastal Range of Taiwan (data from Chen, 1975). Average $Y$-values for orogenic andesites from the SW Pacific arcs are also shown (Ewart, 1979). Symbols as in Fig. 3.

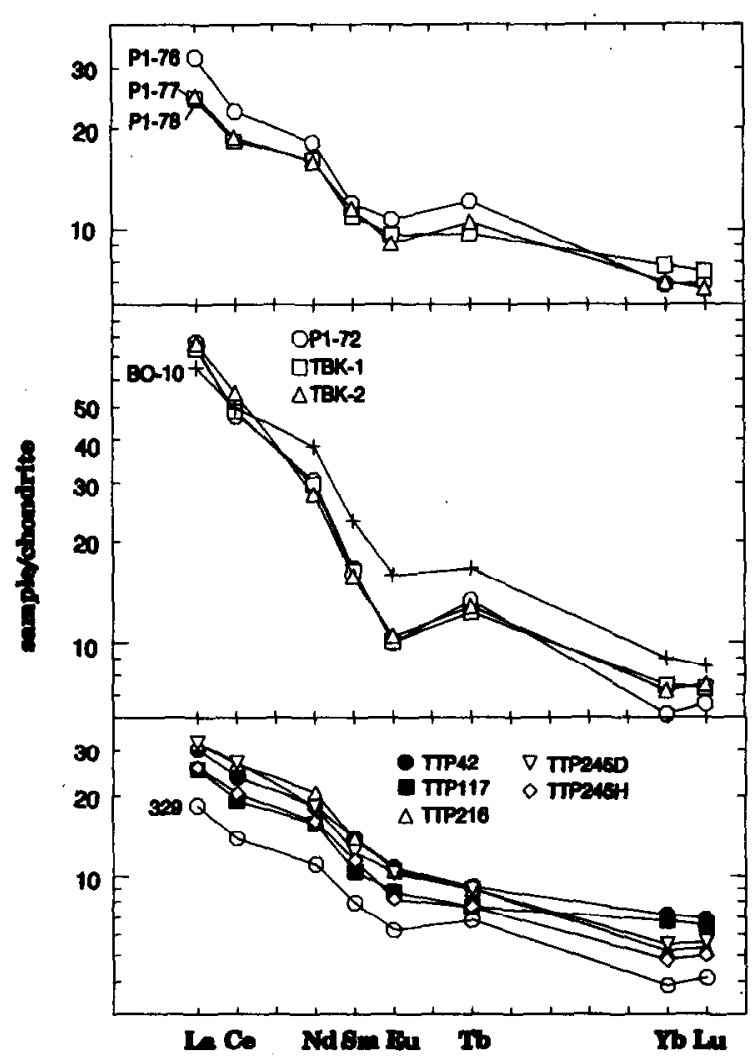

Fig. 5. REE values for the analyzed samples, normalized to the chondritic values of Nakamura (1974) following the suggestions of Rock (1987).
(Chen, 1975). However, several samples are strongly enriched in Ba. The medium-K calc-alkaline suite of the Tabuk Plugs and the intrusives of the Bokod area are enriched in all trace elements relative to the Quirino and Posdo samples.

REE concentrations show enrichment in the light REE (LREE) relative to the heavy REE (HREE) (Fig. 5) for all samples. Dacites from the western centers, excluding $\mathrm{Pl}-72$, i.e. the low-K samples have $\mathrm{La}(n)=20-35$ and $\mathrm{Yb}(n)=4-8$. The Tabuk, Bokod and Banauwe samples are more LREE enriched $[\mathrm{La}(n)=65-75]$, but have similar low HREE as the low-K samples, consistent with the low $Y$ abundances. In addition, they exhibit distinct Eu-anomalies.

\section{Mineral Chemistry}

\section{Amphibole}

Amphibole, which is ubiquitous in our samples, is relatively $\mathrm{Ca}$-rich with $1.8-1.9 \mathrm{Ca}$ per formula unit (on the basis of $23 \mathrm{O}$ ), except for the Posdo amphiboles, which may contain as little as $1.6 \mathrm{Ca}$ (Table 3 ). There are distinct compositional differences between amphiboles from the low- $\mathrm{K}$ and $\mathrm{K}$-rich suites and between amphiboles from the western and eastern centers, respectively. The amphiboles from the western centers are $\mathrm{Mg}$-rich $[\mathrm{Mg} /(\mathrm{Mg}+\mathrm{Fe})>0.65]$ as opposed to those of the eastern centers $[\mathrm{Mg} /(\mathrm{Mg}+\mathrm{Fe}$ ) < 0.65] (Fig. 6). The low-K suites contain amphiboles with less than $0.08 \mathrm{~K}$ per formula unit, while the normal and high-K suites contain amphiboles with $0.08-0.22 \mathrm{~K}$ (Fig. 6). The high $\mathrm{K}$ content in the Banawue amphiboles is good evidence that the relatively high potassium content in the whole rock analysis is a primary feature.

The Al-content is quite variable within individual samples even if only rim compositions are considered. $\mathrm{Al}^{\mathrm{IV}}$ and $\mathrm{Al}^{\mathrm{VI}}$ correlate with the total $\mathrm{Al}$-content, but in an $\mathrm{Al}^{\mathrm{VI}} / \mathrm{Al}^{\text {tot }}$ plot the individual complexes show different trends. The amphiboles from the Posdo complex are distinctly low in $\mathrm{Al}, \mathrm{Ca}$ and $\mathrm{Ti}$. The small number of phases present in the lavas (plagioclase, amphibole and spinel) precludes the use of the Al contents in the amphiboles as a geobarometer (see discussion in Hollister et al., 1987).

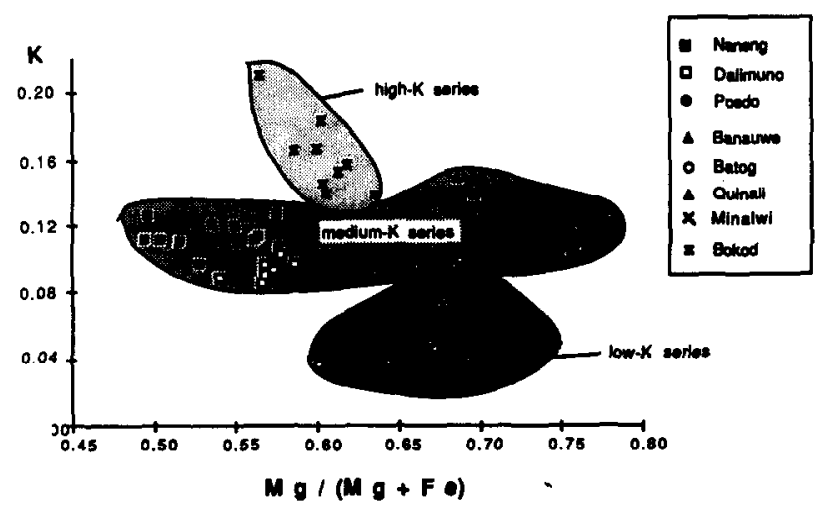

Fig. 6. $\mathrm{K}$ vs $\mathrm{Mg} /(\mathrm{Mg}+\mathrm{Fe})$ for amphiboles (on the basis of 23 O) illustrating the relationships between $\mathrm{K}$-contents in amphibole and in the host rock. 
Table 3. Selected amphibole analyses for Late-Miocene volcanic rocks from the Northern Luzon segment

\begin{tabular}{|c|c|c|c|c|c|c|c|c|c|c|}
\hline \multirow{2}{*}{$\begin{array}{l}\text { Complex } \\
\text { Sample }\end{array}$} & \multicolumn{2}{|c|}{ Batog } & \multicolumn{2}{|c|}{ Posdo } & \multicolumn{2}{|c|}{ Banawue } & \multicolumn{2}{|c|}{ Naneng } & \multicolumn{2}{|c|}{ Bokod } \\
\hline & P1-76 & P1-76 & TTP216 & TTP216 & P1-72 & $\mathrm{P} 1-72$ & TBK4 & TBK4 & BO10 & BO10 \\
\hline $\mathrm{SiO}_{2}$ & 40.90 & 40.85 & 45.59 & 48.15 & 43.15 & 41.48 & 41.90 & 42.64 & 41.75 & 44.11 \\
\hline $\mathrm{TiO}_{2}$ & 1.63 & 1.38 & 0.88 & 0.94 & 1.64 & 1.15 & 1.99 & 1.64 & 2.07 & 1.68 \\
\hline $\mathrm{Al}_{2} \mathrm{O}_{3}$ & 13.36 & 12.05 & 8.62 & 6.72 & 11.69 & 13.42 & 10.85 & 9.61 & 10.49 & 8.34 \\
\hline $\mathrm{MgO}$ & 13.60 & 12.74 & 14.66 & 15.70 & 16.56 & 13.70 & 11.22 & 10.87 & 12.92 & 13.52 \\
\hline $\mathrm{CaO}$ & 10.84 & 12.34 & 10.53 & 10.48 & 11.16 & 11.28 & 11.31 & 11.68 & 11.42 & 11.71 \\
\hline $\mathrm{MnO}$ & 0.25 & 0.38 & 0.59 & 0.52 & 0.07 & 0.12 & 0.43 & 0.60 & 0.42 & 0.48 \\
\hline $\mathrm{FeO}$ & 13.41 & 15.08 & 13.38 & 12.35 & 9.17 & 12.27 & 15.60 & 16.77 & 14.19 & 13.81 \\
\hline $\mathrm{Na}_{2} \mathrm{O}$ & 2.13 & 1.66 & 1.42 & 1.21 & 2.21 & 2.30 & 2.00 & 1.66 & 2.15 & 1.78 \\
\hline $\mathrm{K}_{2} \mathrm{O}$ & 0.20 & 0.19 & 0.31 & 0.18 & 0.65 & 0.52 & 0.57 & 0.62 & 0.81 & 0.72 \\
\hline $\mathrm{F}$ & 0.01 & 0.02 & 0.05 & 0.13 & 0.11 & 0.15 & 0.09 & 0.04 & 0.08 & 0.14 \\
\hline $\mathrm{Cl}$ & 0.00 & 0.02 & 0.07 & 0.05 & 0.02 & 0.02 & 0.15 & 0.11 & 0.07 & 0.06 \\
\hline $\mathrm{H}_{2} \mathrm{O}_{\text {calk }}$ & 1.99 & 1.97 & 1.97 & 1.96 & 1.98 & 1.93 & 1.89 & 1.91 & 1.92 & 1.90 \\
\hline Total & 98.32 & 98.68 & 98.07 & 98.39 & 98.41 & 98.33 & 98.00 & 98.15 & 98.29 & 98.25 \\
\hline $\mathrm{Si}$ & 6.134 & 6.183 & 6.803 & 7.085 & 6.342 & 6.201 & 6.400 & 6.539 & 6.338 & 6.660 \\
\hline $\mathrm{Al}^{\mathrm{IV}}$ & 1.866 & 1.817 & 1.197 & 0.915 & 1.658 & 1.799 & 1.600 & 1.461 & 1.662 & 1.340 \\
\hline $\mathrm{Al}^{\mathrm{VI}}$ & 0.495 & 0.333 & 0.318 & 0.251 & 0.367 & 0.465 & 0.354 & 0.276 & 0.214 & 0.144 \\
\hline $\mathrm{Ti}$ & 0.184 & 0.158 & 0.099 & 0.104 & 0.181 & 0.129 & 0.229 & 0.189 & 0.236 & 0.190 \\
\hline Mg & 3.040 & 2.874 & 3.261 & 3.444 & 3.627 & 3.052 & 2.555 & 2.484 & 2.924 & 3.044 \\
\hline $\mathrm{Ca}$ & 1.741 & 2.001 & 1.684 & 1.653 & 1.757 & 1.807 & 1.850 & 1.919 & 1.858 & 1.895 \\
\hline Mn & 0.032 & 0.048 & 0.075 & 0.065 & 0.009 & 0.015 & 0.056 & 0.078 & 0.054 & 0.062 \\
\hline $\mathrm{Fe}$ & 1.682 & 1.909 & 1.670 & 1.520 & 1.127 & 1.533 & 1.993 & 2.150 & 1.801 & 1.744 \\
\hline $\mathrm{Na}$ & 0.618 & 0.486 & 0.410 & 0.344 & 0.630 & 0.667 & 0.593 & 0.494 & 0.632 & 0.520 \\
\hline K & 0.038 & 0.037 & 0.059 & 0.034 & 0.122 & 0.099 & 0.112 & 0.121 & 0.157 & 0.138 \\
\hline
\end{tabular}

Structural formulae based on $23 \mathrm{O}$, Fe calculated as $\mathrm{Fe}^{2+}$.

\section{Pyroxene}

Clinopyroxene is very rare and appears to be of xenocrystic origin. Its compositional similarity to the clinopyroxenes, that occur as relicts in the Lepanto Metavolcanic rocks, suggests their derivation from these rocks (Table 4).

\section{Biotite}

Biotite is found in only two of the Posdo samples and in the Bokod sample investigated here. In one of the Posdo samples the biotite is clearly xenocrystic as indicated by the fragmented nature of the flakes. In the second sample (TTP169), enriched in $K_{2} \mathrm{O}$ relative to

Table 4. Composition of clinopyroxenes from sample TTP 46 from the Lepanto Metavolcanics and sample P1-72 from the Quinali Plug

\begin{tabular}{|c|c|c|c|c|c|c|c|}
\hline \multirow{2}{*}{$\begin{array}{l}\text { Sample } \\
\text { Analysis }\end{array}$} & \multicolumn{5}{|c|}{ TTP 46} & \multicolumn{2}{|c|}{$\mathrm{Pl} 1.72$} \\
\hline & 2 & 8 & 12 & 13 & 14 & 2 & 3 \\
\hline $\mathrm{SiO}_{2}$ & 50.71 & 51.99 & 51.77 & 50.20 & 49.76 & 50.33 & 52.28 \\
\hline $\mathrm{TiO}_{2}$ & 0.56 & 0.17 & 0.20 & 0.61 & 0.75 & 0.50 & 0.37 \\
\hline $\mathrm{Fe}_{2} \mathrm{O}_{3}$ & 2.34 & 1.86 & 2.20 & 3.34 & 3.16 & 3.76 & 2.03 \\
\hline $\mathrm{Al}_{2} \mathrm{O}_{3}$ & 3.40 & 3.08 & 2.43 & 2.52 & 2.76 & 3.26 & 2.07 \\
\hline $\mathrm{Cr}_{2} \mathrm{O}_{3}$ & 0.04 & 0.55 & 0.16 & 0.01 & 0.02 & 0.22 & 0.17 \\
\hline $\mathrm{MgO}$ & 16.12 & 17.47 & 17.15 & 14.88 & 14.89 & 15.42 & 16.38 \\
\hline $\mathrm{FeO}$ & 4.63 & 1.76 & 2.90 & 6.67 & 6.52 & 3.43 & 3.56 \\
\hline $\mathrm{MnO}$ & 0.19 & 0.08 & 0.14 & 0.24 & 0.22 & 0.13 & 0.12 \\
\hline $\mathrm{CaO}$ & 20.81 & 22.42 & 21.62 & 20.09 & 19.92 & 21.87 & 22.56 \\
\hline $\mathrm{Na}_{2} \mathrm{O}$ & 0.20 & 0.13 & 0.17 & 0.30 & 0.30 & 0.34 & 0.23 \\
\hline Total & 98.99 & 99.52 & 98.75 & 98.87 & 98.30 & 99.25 & 99.79 \\
\hline $\mathrm{Si}$ & 1.884 & 1.900 & 1.915 & 1.890 & 1.883 & 1.867 & 1.923 \\
\hline $\mathrm{Ti}$ & 0.016 & 0.005 & 0.006 & 0.017 & 0.021 & 0.014 & 0.010 \\
\hline $\mathrm{Al}^{\mathrm{IV}}$ & 0.116 & 0.100 & 0.085 & 0.110 & 0.117 & 0.133 & 0.077 \\
\hline $\mathrm{Al}^{\mathrm{Vl}}$ & 0.033 & 0.033 & 0.021 & 0.002 & 0.006 & 0.031 & 0.011 \\
\hline $\mathrm{Fe}^{3+}$ & 0.065 & 0.051 & 0.061 & 0.095 & 0.090 & 0.091 & 0.057 \\
\hline $\mathrm{Cr}$ & 0.001 & 0.016 & 0.005 & 0.000 & 0.001 & 0.006 & 0.005 \\
\hline $\mathbf{M g}$ & 0.893 & 0.952 & 0.945 & 0.835 & 0.840 & 0.853 & 0.898 \\
\hline $\mathrm{Fe}^{\mathrm{J}+}$ & 0.144 & 0.054 & 0.090 & 0.210 & 0.206 & 0.106 & 0.110 \\
\hline $\mathrm{Mn}$ & 0.006 & 0.002 & 0.005 & 0.008 & 0.007 & 0.004 & 0.004 \\
\hline $\mathrm{Ca}$ & 0.828 & 0.878 & 0.856 & 0.811 & 0.807 & 0.869 & 0.889 \\
\hline $\mathrm{Na}$ & 0.015 & 0.009 & 0.012 & 0.022 & 0.022 & 0.025 & 0.016 \\
\hline
\end{tabular}

Structural formula on the basis of six oxygen. 


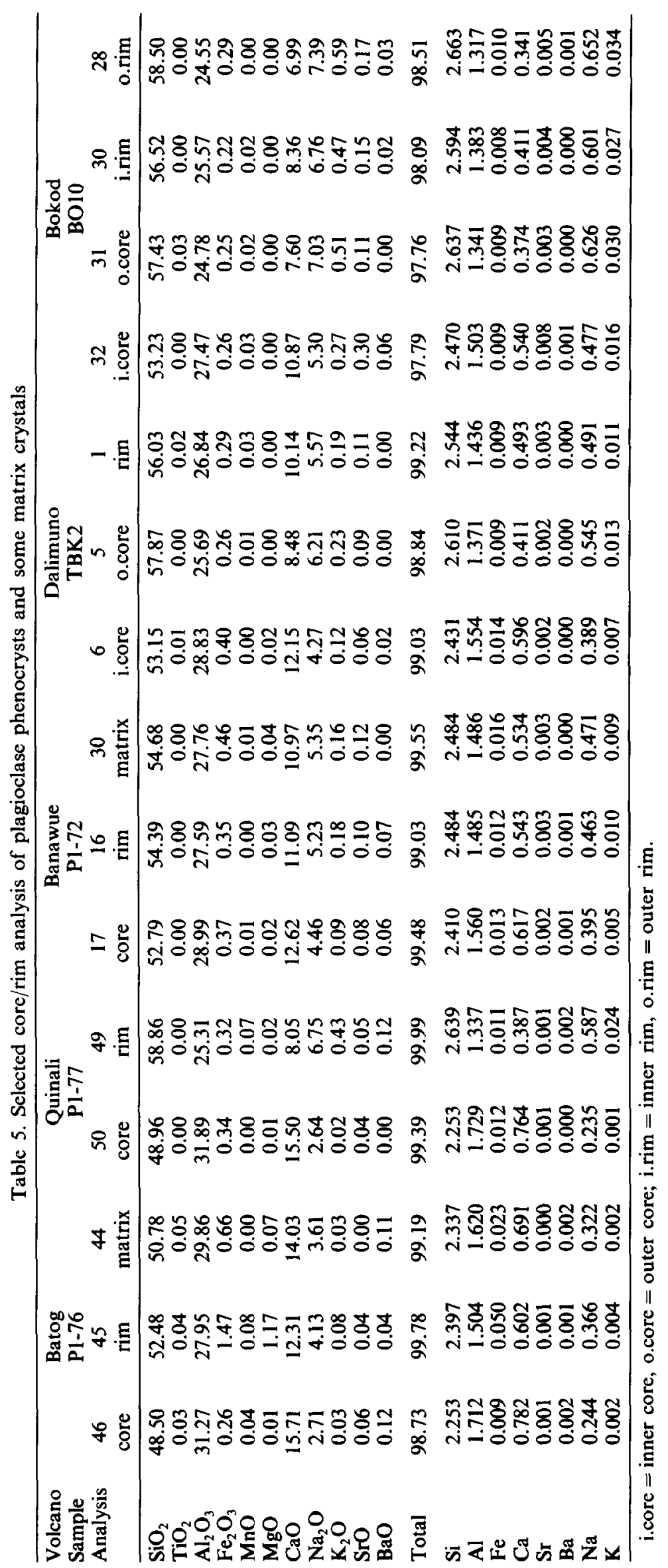




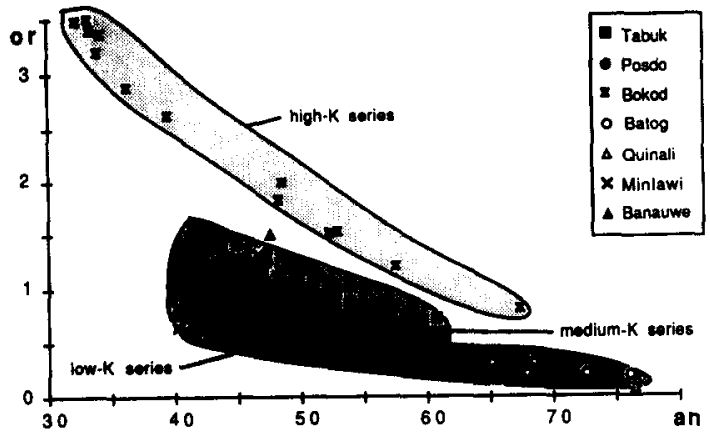

Fig. 7. Or plotted vs An for core compositions of plagioclase phenocrysts.

other Posdo samples, the biotite forms large, well defined tabular crystals, suggesting primary crystallization from the melt (secondary biotite, which is ubiquitous close to the porphyry mineralization forms aggregates of fine biotite flakes, which bear no similarity to the primary crystals of sample TTP169).

\section{Plagioclase}

Phenocrystic plagioclase exhibits a wide range in composition in all samples (Table 5, Fig. 7), except those of the Posdo complex, where phenocrysts within a single sample have a compositional range of only $5 \mathrm{~mol} \% \mathrm{An}$. Samples from the Naneng and Dalimuno Plugs with $\mathrm{An}_{42-60}$ show moderate variation in core composition and relatively uniform groundmass plagioclase compositions with $\mathrm{An}_{36-40}$ in the Naneng samples and $A n_{57-60}$ in the Dalimuno sample. The greatest variations are found in the low-K Batog sample $\left(\mathrm{An}_{40-76}\right)$ and the Bokod sample $\left(\mathrm{An}_{31-67}\right)$. Compared to plagioclase from other low-K suites, the plagioclase in the lavas from the Mankayan and Quirino areas is relatively sodic (e.g. plagioclase in Tonga dacites has $\mathrm{An}_{60-80}$, Ewart, 1979).

There are notable differences with regard to the Or contents in plagioclase cores from the low-K, medium$\mathrm{K}$, and the high- $\mathrm{K}$ rocks, respectively, though plagioclase in the low-K Posdo and medium-K Tabuk samples have similar compositions (Fig. 7). For rim compositions the distinction among the series becomes less clear, because rims are often distinctly more Or-rich than the cores (except in the Batog sample) and evolve towards the field of the Or-rich Bokod plagioclase. A similar crude correlation between the polassium contents in plagioclase and the potassium contents in the host rock was described for medium- $\mathrm{K}$ and high- $\mathrm{K}$ series from the Marianas arc (Bloomer et al., 1989). Among the Quirino samples, the Banawue sample plagioclase is notable for its high $\mathrm{K}$ contents (similar to the amphibole) and confirms the high $\mathrm{K}_{2} \mathrm{O}$ contents found for the whole rock analysis.

\section{Spinel}

Spinel is a ubiquitous phase in all of our samples. It is nearly pure magnetite in the Bokod and Tabuk samples with $0-10 \% \mathrm{Fe}^{3+}$ replaced by $\mathrm{Ti}$ and $\mathrm{V}$, while in the Posdo and Quirino samples an additional amount of $\mathrm{Fe}^{2+}$ (up to $17 \%$ ) may be replaced by $\mathrm{Mg}$ and $\mathrm{Zn}$ $\left(\mathrm{Fe}^{2+} / \mathrm{Fe}^{3+}\right.$ calculated on the basis of three cations and four oxygens).

\section{Sr Isotopic Compositions}

Twelve new ${ }^{87} \mathrm{Sr} /{ }^{86} \mathrm{Sr}$ ratios are given in Tables 1 and 2. In view of the very low $\mathrm{Rb} / \mathrm{Sr}$ ratio of most samples and their young age, no age corrections are required.

The low-K rocks from Mt Quinali, the Banawue Plug, and the Batog Plug in the Quirino area have the lowest ${ }^{87} \mathrm{Sr}{ }^{86} \mathrm{Sr}$ ratios $(0.70354-0.70363)$ of all samples studied. Sample P1-78 from the Minlawi Plug, which contains somewhat more radiogenic $\mathrm{Sr}(0.70382)$, is the most altered sample, and thus the measured value may not reflect the Sr-isotopic composition of the magma. The two samples from the Posdo complex have slightly more radiogenic Sr $(0.70372-0.70377)$ compared to the Quirino samples (excluding P1-78). The reported values for the Baguio area (Divis, 1983; Defant et al., 1990), including a new analysis (Table 2), fall into the same range.

In contrast, the medium- $\mathrm{K}$ rocks from the Dalimuno and Naneng Intrusions $\left({ }^{87} \mathrm{Sr} /{ }^{86} \mathrm{Sr}: 0.70396\right.$ and 0.70413 , respectively), contain distinctly more radiogenic $\mathrm{Sr}$ than the low-K volcanics from the western part of the Cordillera. On the other hand, our sample from the Bokod area, which is even more enriched in LILE and also comes from the eastern part of the Cordillera, has $\mathrm{Sr}$ isotopic composition similar to the Quirino samples, i.e. at present it is not clear whether a correlation between ${ }^{87} \mathrm{Sr} /{ }^{86} \mathrm{Sr}$ and LILE contents exists.

The observed ratios are clearly lower than those reported for the southern segments of the Luzon arc ${ }^{87} \mathrm{Sr}{ }^{86} \mathrm{Sr}$ : 0.7042-0.7051, Knittel and Defant, 1988) and confirm the earlier suggestion of Divis (1983) and Defant et al. (1990) that NLS volcanism is characterized by relative low ${ }^{87} \mathrm{Sr} /{ }^{86} \mathrm{Sr}$.

\section{Discussion}

\section{Regional geochemical variations}

The late Miocene volcanic rocks of the NLS are distinct from those of the Bashi and Bataan segments to the north and south in that they are limited to relatively high $\mathrm{SiO}_{2}$ contents. The mafic mineralogy is dominated by amphibole, while the lavas of the Bataan Segments are dominated by anhydrous phenocryst assemblages (Defant et al., 1991), although amphibole-bearing lavas are present at Mt Pinatubo and Mt Arayat (Bernard et al., in press; Knittel and Bau, unpublished data). Evolved lavas in the Bashi Segment have two pyroxene or clinopyroxene \pm amphibole phenocryst associations (Jacques, 1987). ${ }^{87} \mathrm{Sr} /{ }^{86} \mathrm{Sr}$ ratios are distinctly lower in the NLS than in the Bataan Segment and less heterogenous than in the Bashi Segment (see below).

Samples of the western centers (Quirino and Lepanto areas) are characterized by very low $\mathrm{K}_{2} \mathrm{O}, \mathrm{Rb}, \mathrm{Zr}$ and $\mathrm{Y}$ concentrations, whereas those from the Tabuk and Bokod areas and some from the Baguio area have elevated LILE. It thus appears that the western centers (closer to the Manila Trench) are characterized by lower LILE concentrations than the eastern centers, except for $\mathrm{Sr}$ and sometimes $\mathrm{Ba}$, which are quite enriched. Within the Baguio area, both low-K and medium-K suites appear to be developed (Maleterre et al., 1988). In contrast, there appears to be little evidence to suggest that ${ }^{87} \mathrm{Sr}{ }^{86} \mathrm{Sr}$ shows a similar variation (though the 
Tabuk centers contain more radiogenic $\mathrm{Sr}$ ), because no increase in ${ }^{87} \mathrm{Sr} /{ }^{86} \mathrm{Sr}$ is found in either the Bokod or the Baguio samples. The reason for the elevated ${ }^{87} \mathrm{Sr} /{ }^{86} \mathrm{Sr}$ in the Tabuk samples is not clear. The host rocks clearly contain sufficiently radiogenic $\mathrm{Sr}\left({ }^{87} \mathrm{Sr} /{ }^{86} \mathrm{Sr}\right.$ : $0.7055-0.7061$, Table 2) to cause increased ${ }^{87} \mathrm{Sr} /{ }^{86} \mathrm{Sr}$ by contamination, but the other plugs probably intrude host rocks containing $\mathrm{Sr}$ of similar composition. It might be noteworthy that the Tabuk samples also contain more than twice as much $\mathrm{Nb}$ and $\mathrm{Ta}$ as the other dacites (including the Bokod sample), suggesting that these magmas are derived from different, more enriched sources.

Previously, Knittel and Defant (1988) suggested that volcanic rocks related to the subduction of the South China Sea crust (Luzon arc) have generally higher ${ }^{87} \mathrm{Sr} /{ }^{86} \mathrm{Sr}(>0.7040)$ than those related to subduction of the Philippine Sea plate $(<0.7040$; pre-Miocene plutonic complexes in northern Luzon and the Bicol arc in southern Luzon). The data presented here and in Defant et al. (1990) show that in the NLS, where volcanism clearly is related to subduction of the South China Sea, ${ }^{87} \mathrm{Sr} /{ }^{86} \mathrm{Sr}$ ratios are identical to the initial ratios of the Oligocene batholiths (Knittel and Defant, 1988; Winter et al., unpublished data). On the island of Batan, located in the north of the Bashi Segment, the older volcanic rocks likewise are characterized by $l o w{ }^{87} \mathrm{Sr} /{ }^{86} \mathrm{Sr}(0.7036-$ 0.7040, Richard, 1986), whereas the younger lavas have higher ${ }^{87} \mathrm{Sr} /{ }^{86} \mathrm{Sr}(0.7044-0.7048$, Richard, 1986).

Knittel and Defant (1988); Knittel et al. (1988) and Defant et al. $(1989,1990)$ argue that even higher ${ }^{87} \mathrm{Sr} /{ }^{86} \mathrm{Sr}$ ratios $\left(>0.7050\right.$ and correlated low ${ }^{143} \mathrm{Nd} /{ }^{144} \mathrm{Nd}$ and elevated LILE and LREE concentrations) observed in the Bashi and Mindoro Segments at the southern and northern ends of the Taiwan-Luzon arc reflect the input of continental material in the vicinity of the collision zones between the Asian continent and the Philippine arc (see Stephan et al., 1986, for a review). The change in the isotopic composition observed for lavas erupted on Batan would indicate the arrival of such material in the magma sources. For the Bashi Segment, however, Chen et al. (1990) consider sediment input as inadequate to explain the observed isotopic signatures and suggest that the enriched signatures are due to the tapping of an enriched EM1-mantle-component (Zindler and Hart, 1986). McDermott et al. (1993) ascribe the unusual isotopic signature to mantle modified by bulk assimilation of sediment and additional contamination by slab derived fluids.

\section{Petrogenesis}

The youngest phase of volcanism in the North Luzon Segment of the Luzon Arc is characterized by the eruption of siliceous andesites and dacites. Within the Mankayan Mineral District and the Quirino area, these siliceous andesites/dacites, with one exception, belong to the low-K calc-alkaline series. These low-K rocks have unusual trace element contents. Sr is extremely enriched, as shown by comparison with the low-K lavas from the Taiwan Segment and compared to average SW Pacific low-K rocks, which contain about $300 \mathrm{ppm} \mathrm{Sr}$ in the range of $60-66 \% \mathrm{SiO}_{2}$ (Ewart, 1979). $\mathrm{Y}$ is much lower (7-12 ppm) than in most investigated arc volcanics (20-25 ppm, Lambert and Holland, 1974); Ewart (1979) gives average values of $19-30 \mathrm{ppm} Y$ for low-K suites in the $60-66 \% \mathrm{SiO}_{2}$ range.

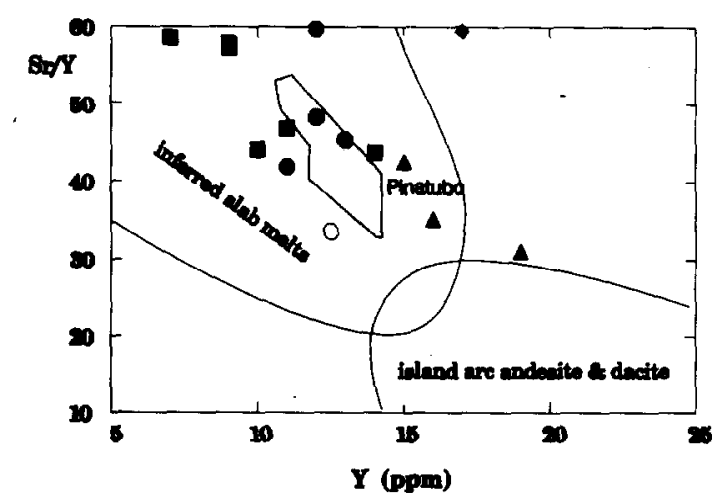

Fig. 8. Sr/Y vs $Y$ plot with fields of supposed slab-derived melts and melts generated by fractionation (based on Defant and Drummond, 1990; Drummond and Defant, 1990). Symbols as in Fig. 3.

Siliceous low-K suites have been interpreted as products of fractional crystallization of low-K precursors (e.g. Tomblin, 1979) or as anatectic melts, generated by partial fusion of the lower crust (e.g. Gill and Stork, 1979; Giese et al., 1986; Smith and Leeman, 1987). Recently, Drummond and Defant (1990) proposed that trondhjemitic/dacitic magmas may be generated by partial fusion of metamorphosed basalt in young ( $<20 \mathrm{~m} . \mathrm{y}$.), still "warm", subducted lithosphere. This model is based on the chemical characteristics of high-Al trondhjemites/dacites ( $\left.\begin{array}{llll}>15 \% & \mathrm{Al}_{2} \mathrm{O}_{3} & \text { at } 70 \% & \mathrm{SiO}_{2}\end{array}\right)$. These rocks generally have high LREE and low HREE contents, suggesting residual garnet in their source. In this model, low $\mathrm{K} / \mathrm{Rb}(<550)$ indicates either residual amphibole in the source or extensive amphibole fractionation. High $\mathrm{Sr}$ contents would result from the lack of plagioclase in the source and lack of extensive plagioclase fractionation.

The geochemistry of the siliceous andesites in the Mankayan District appears to be appropriate for the Drummond and Defant model to be applied. We note that $Y$ and the HREE, which are compatible in garnet, are consistently low in the Mankayan rocks compared to the commonly observed range, as noted above. In particular, in an $\mathrm{Sr} / \mathrm{Y}$ vs $\mathrm{Y}$ plot, the Quirino and Posdo samples clearly plot in the field defined by lavas of inferred slab origin (Fig. 8). Furthermore, since the area is located where the youngest part of the South China Sea ridge is subducted, the subducted lithosphere underlying this area was young ( $<14 \mathrm{~m} . \mathrm{y}$.) at the time of dacite volcanism. On the other hand, $Y$ and HREE are also compatible in amphibole and, thus, extensive amphibole fractionation could also be responsible for the low $Y$ and HREE concentrations and would also account for the low $\mathrm{K} / \mathrm{Rb}$ ratios.

Calculations of the REE concentrations of eclogitederived meits do not support an eclogite-melting model. Experiments of Rapp et al. (1991) have shown that the residue of melted basaltic compositions at 22 and $32 \mathrm{kbar}$ is composed essentially of garnet and clinopyroxene with minor amounts of rutile, magnetite and rarely plagioclase. The amount of garnet in the residue usually surpasses $30 \%$. Model calculations using high $K_{\mathrm{d}}$ values for $R E E_{\text {(garnet-melt) }}$ (we used the values in Martin, 1987) show melts derived from either $\mathrm{N}$ - or E-MORB have similar REE patterns as the NLS dacites only if the amount of garnet in the residue is small $(<10 \%)$ and the degree of partial melting high $(>25 \%$ ) (Fig. $9 a, c)$. $\mathrm{Yb}(n)<6$ 

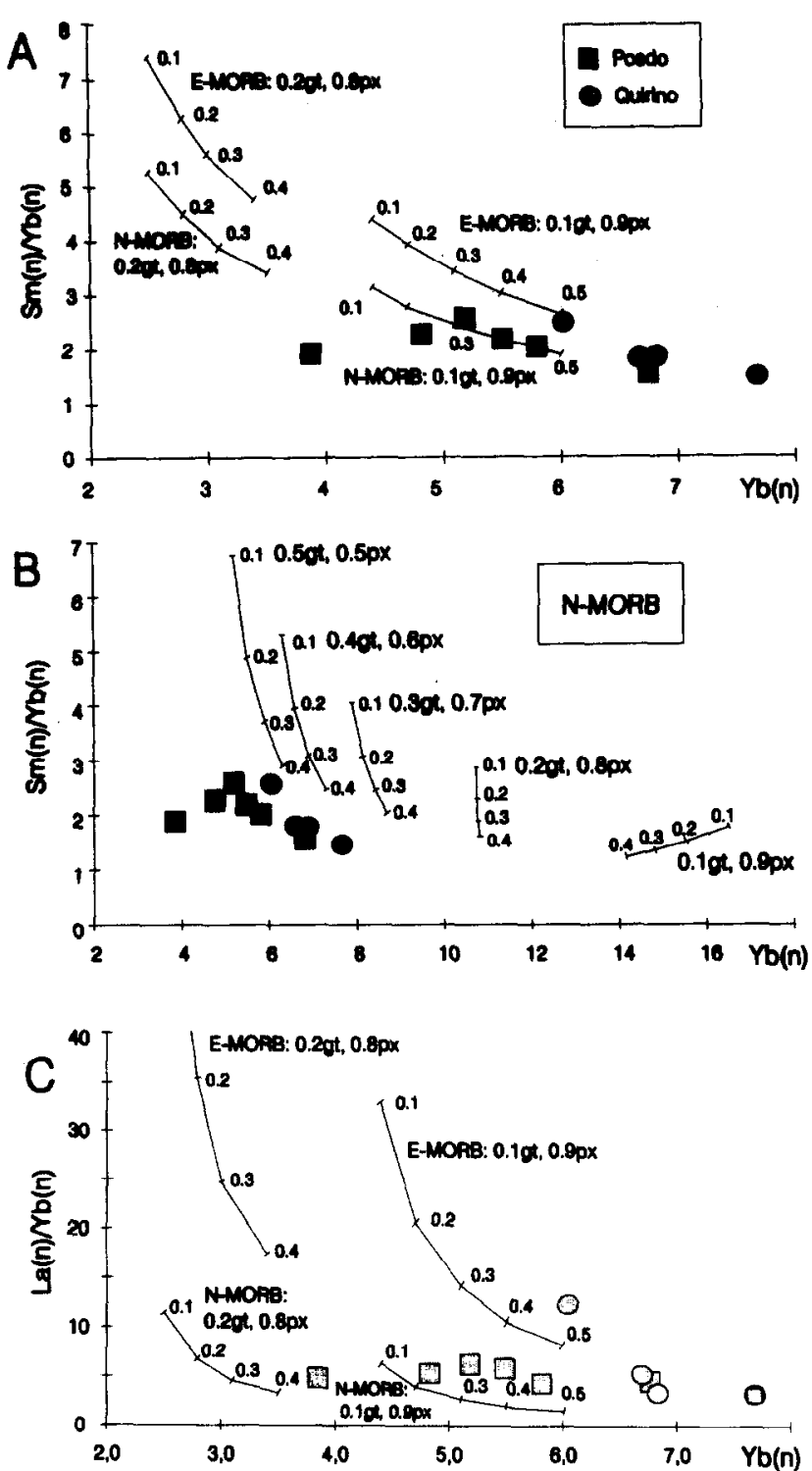

Fig. 9. Calculated chondrite-normalized $\mathrm{Sm} / \mathrm{Yb}, \mathrm{La} / \mathrm{Yb}$ and $\mathrm{Yb}$ for magmas generated by melting of $\mathrm{N}$ - and $\mathrm{E}-\mathrm{MORB}$ (MORB data from Jahn, 1986) in eclogite facies using the $K_{\mathrm{d}}$-values of Martin (1987) (A, C) and Kay (1980) (B), respectively. Numbers following "Morb"-labels are residue compositions ( $\mathrm{gt}=$ garnet, $\mathrm{px}=$ clinopyroxene). Ticks at the curves indicate the degree of partial melting.

could be accounted for if the applicable $K_{d}$ values for $R E E_{(\text {garnet-melt) }}$ are slightly lower than those chosen by Martin (1987). If low $K_{d}$ values are applied, e.g. those used by Kay (1978), high amounts of residual garnet $(\geqslant 50 \%)$ and high degrees of partial melting are required to produce patterns as observed for the NLS magmas (Fig. 9b). However, such low $K_{\mathrm{d}}$ values appear to be more appropriate for basaltic melts (cf. Irving and Frey, 1978).

There are several features indicating that the NLS low-K rocks do not form a suite related by fractional crystallization to basaltic precursors, the most obvious one being the large scatter in LILE. To explain the unusual low $Y$ and HREE contents it would be necessary that large amounts of amphibole were fractioned, while at the same time the high $\mathrm{Sr}$ contents argue against extensive fractionation of plagioclase. Alternatively, the high $\mathrm{Sr}$ contents could be due to accumulation of plagioclase, but this is not supported for the Posdo samples,

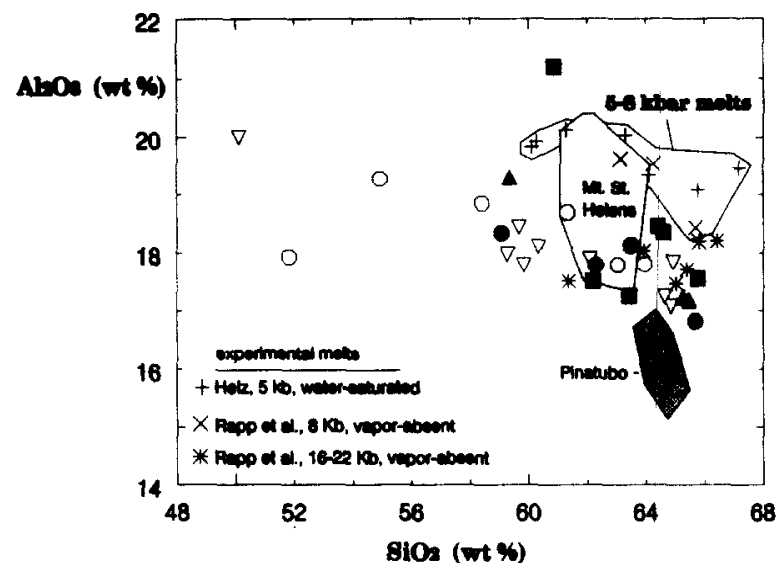

Fig. 10. $\mathrm{Al}_{2} \mathrm{O}_{3}$ vs $\mathrm{SiO}_{2}$ for North Luzon samples (symbols: see Fig. 3) compared to melts experimentally produced by melting of basaltic starting compositions (Helz, 1976; Rapp et al., 1991). Fields for Mt St Helens (light colour, data from Smith and Leeman, 1987) and Pinatubo dacites (dark colour, data from Bernard $e t$ al., in press) are shown for comparison. Symbols as in Fig. 3.

in which plagioclase shows only very limited compositional variation (Fig. 7). Furthermore, the amphiboles in the low-K samples have high $\mathrm{Mg} /(\mathrm{Mg}+\mathrm{Fe}$ ) (Fig. 6), unlike amphiboles crystallizing from highly fractionated melts.

The third possible genetic model commonly discussed for dacites is melting of amphibolite in the lower crust. This process is difficult to model in detail because the composition of the lower crust and the residue are uncertain. Rapp et al. (1991) found various assemblages of plagioclase + amphibole \pm garnet + minor phases at pressures between 8 and $16 \mathrm{kbar}$. Qualitatively, melting of an amphibolite would account for the low $Y$ and HREE contents of the low-K suite, if a small amount of garnet remains in the residue (see Fig. 9a, c), while the high $\mathrm{Sr}$ content is not readily explained. Melting at crustal levels may have been promoted by the tectonic setting of the NLS, because the high elevation of the Cordillera could prevent mafic magmas from rising to the surface resulting in intrusion at crustal levels. Mafic magma stored at lower crustal levels could have heated the host rocks above their solidus. However, compared to melts, experimentally produced by melting of basaltic starting materials at pressures between 5 and $8 \mathrm{~kb}$ ( $\mathrm{Helz}$, 1976; Rapp et al., 1991), the dacites are low in $\mathrm{Al}_{2} \mathrm{O}_{3}$ (Fig. 10), though they are high in $\mathrm{Al}_{2} \mathrm{O}_{3}$ compared to other dacites from arcs (e.g. 15\% for Tonga dacites in the $60-63 \% \mathrm{SiO}_{2}$-range; Ewart, 1979).

Finally it should be noted that the low-K suite may have been generated by a combination of several processes, e.g. by mixing of differentiated magma, derived from basic precursors, with anatectic melts. Because the lower crust of the arc and the subducted South China Sea crust are likely to have similar isotopic compositions, such mixing might not be seen in isotopic systematics.

Acknowledgements-U.K. wishes to thank $T$ Duyan and M. A. Credo for their hospitality in Tabuk, T. Bernecker for providing descriptions of the sediment samples from the Tabuk area, M. Haukka for help with the XRF and XRD analyses, and $D$. Sewell and P. Kelly for help with the microprobe. A.G.T. acknowledges support for field work at the Tirad prospect by Renison Goldfields Exploration (Australia). 
W.W. thanks Benguet Corporation for logistical support. Achim Albrecht determined the $\mathrm{Sr}$ isotopic composition of sample P1-71 at the University of New Mexico, Albuquerque. Comments of M. J. Defant, K. Hattori and J.-C. Ringenbach on an earlier version and by $D$. Smith on a later version of the manuscript resulted in substantial improvements.

\section{REFERENCES}

Alvir A. D. (1956) A cluster of little known Philippine volcanoes. Proc. 8th Pacific Sci. Congr., Manila. 1953. Vol. 2. pp. 205-206.

Baker E. M. (1983) The geological setting of copper-gold mineralization in the Mankayan district, northern Luzon, Philippines: Gold Fields Asia Ltd, unpublished report no. PI3/1984, $67 \mathrm{pp}$.

Balce G. R. (1979) Geology and ore genesis of the porphyry copper deposits in Baguio District, Luzon Island, Philippines. J. Geol. Soc. Philipp. 33, 1-43.

Balce G. R., Encina R. Y., Momongan A. and Lara E. (1980) Geology of the Baguio District and its implication on the tectonic development of the Luzon Central Cordillera. Geol. Paleontol. SE Asia 21, 265-287.

Barsdell M. and Berry R. F. (1990) Origin and evolution of primitive island arc ankaramites from western Epi, Vanuatu. J. Petrol. 31, 747-777.

Bernard A., Knittel U., Weber B., Weis D., Albrecht A., Hattori K., Klein J., Oles D. Petrology and geochemistry of the 1991 eruption products of Ult Pinatubo (Luzon, Philippines). In The 1991 Eruption of Ult Pinatubo (Edited by C. G. Newhall and R. S. Punangbayan), USGS-PhiVols, special paper (in press).

Bloomer S. H., Stern R. J., Fisk E. and Geschwind C. H. (1989) Shoshonitic volcanism in the northern Marianas Arc. 1. Mineralogic and major and trace element characteristics. J. Geophys. Res. 94, 4469-4496.

de Boer J. Z., Odom L. A., Ragland P. C., Snider F. G. and Tilford N. R. (1980) The Bataan Orogene: eastward subduction, tectonic rotations and volcanism in the western Pacific (Philippines). Tect mophysics 67, 251-282.

Bryner L. (1969) Ore deposits in the Philippines-an introduction to their geology. Econ. Geol. 64, 644-666.

Caagusan N. L. (1980) Stratigraphy and evolution of the Cagayan Valley Basin, Luzon, Philippines. Geol. Paleontol. SE Asia 21, 163-182.

Chen Chang-Hwa, Shieh Y.-N., Lee T., Chen Cheng-Hong and Mertzman S. A. (1990) Nd-Sr-O isotopic evidence for source ccntamination and unusual mantle component under Luzon Arc, Philippines. Geochim. Cosmochim. Acta 54, 2473-2483.

Chen J.-C. (1975) Geochemistry of andesites from the Coastal Range, eastern Taiwan. Proc. Geol. Soc. China 18, 73-88.

Christian L. B. (1964) Post-oligocene tectonic history of the Cagayan Basin, Philippines. Philipp. Geol. 18, 114-147.

Conception R. A. and Cinco J. C. Jr (1989) Geology of Lepanto Far Southeast gold-rich porphyry copper deposit, Mankayan, Benguet, Philippines. 28th Int. Geological Congr. Abstr. Vol. 1, pp. 319-320.

Defant M. J. (1985) The potential origin of the potassiumdepth relationship in the Bataan Orogene, the Philippines. Unpublished Ph.D. thesis, Florida State University, Tallahassee, FL, $622 \mathrm{pp}$.

Defant M. J. and Drummond M. S. (1990) Derivation of some modern arc magmas by melting of young subducted lithosphere. Nature 347, 662-665.

Defant M. J., De Boer J. Z. and Oles D. (1988) The western Central Luzon volcanic arc, the Philippines: two arcs divided by rifting? Tectonophysics 145, 305-317.

Defant M. J., Jacques D., Maury R. C. and De Boer J. Z. (1989) Geochemistry and tectonic setting of the Luzon arc, the Philippines. Bull. Geol. Soc. Am. 101, 663-672.

Defant M. J., Maury R. C., Joron J. L., Feigenson M. D., Leterrier J., Bellon H., Jacques D. and Richard M. (1990) The geochemistry of the northern Luzon, Babuyan and Taiwan segments of the Luzon arc, the Philippines. Tectonophysics 183, 187-205.
Defant M. J., Maury R. C., Ripley E. M., Feigenson M. D. and Jacques D. (1991) An example of island-arc petrogenesis: geochemistry and petrology of the southern Luzon arc. Philippines. J. Petrol. 32, 455-500.

Divis A. F. (1980) The petrology and tectonics of Recent volcanism in the central Philippine Islands. In The Tectonic and Geological Evolution of Southeast Asian Seas and Islands (Edited by D. E. Hayes), pp. 127-144. American Geophysical Union Monograph 23.

Divis A. F. (1983) The geology and geochemistry of Philippine porphyry copper deposits. In The Tectonic and Geologic Evolution of Southeast Asian Seas and Islands: Part 2 (Edited by D. E. Hayes), pp. 173-216. American Geophysical Union Monograph 27.

Drummond M. S. and Defant M. J. (1990) A model for trondhjemitetonalite-dacite genesis and crustal growth via slab melting: Archean to modern comparisons. J. Geophys. Res. 95, 21503-21521.

Durkee E. F. and Pederson S. L. (1961) Geology of northern Luzon, Philippines. Am. Assoc. Petrol. Geol. Bull. 45, 137-168.

Ewart A. (1979) A review of the mineralogy and chemistry of TertiaryRecent dacitic, latitic, rhyolitic and related rocks. In Trondhjemites, Dacites, and Related Rocks (Edited by F. Barker), pp. 13-121. Developments in Petrology 6, Elsevier, Amsterdam.

Fernandez H. E. and Damasco F. V. (1979) Gold deposition in the Baguio Gold District and its relationship to regional geology. Econ. Geol. 74, 1852-1868.

Fernandez J. C. and Pulanco D. H. (1967) Reconnaissance geology of northwestern Luzon, Philippines. Proc. 2nd Geol. Convention, Geol. Soc. Philippines, Vol. 1, pp. 35-44.

Förster H., Oles D., Knittel U., Defant M. J. and Torres R. C. (1990) The Macolod Corridor: a rift crossing the Philippine island arc. Tectonophysics 183, 265-271.

Garcia J. S. (1990) Geology and mineralization characteristics of the Mankayan Mineral District, Beguet, Philippines. Symp. HighTemperature Acid Fluids and Associated Alteration and Mineralization, pp. 17-25. Geological Survey, Japan.

Giese U., Knittel U. and Kramm U. (1986) The Paracale Intrusion: geologic setting and petrogenesis of a trondhjemite intrusion in the Philippine Island Arc. J. Southeast Asian Earth Sci. 1, 235-245.

Gill J. B. and Stork A. L. (1979) Miocene low-K dacites and trondhjemites of Fiji. In Trondhjemites, Dacites and Related Rocks (Edited by F. Barker), pp. 629-649. Developments iı Petrology 6, Elsevier, Amsterdam.

Gonzales A. (1956) Geology of the Lepanto Copper Mine, Mankayan, Mountain Province. In Copper Deposits of the Philippines (Edited by A. Kinkel), pp. 17-50. Philippine Bureau of Mines Special Projects Series 16.

Gray C. M. (1987) Strontium isotopic constraints on the origin of Proterozoic anorthosites. Precam. Res. 37, 173-189.

Hayes D. E. and Lewis S. D. (1984) A geophysical study of the Manila Trench, Luzon, Philippines 1 . Crustal structure, gravity, and regional tectonic evolution. J. Geophys. Res. 89, 9171-9195.

Helz R. T. (1976) Phase relations of basalts and their melting ranges at $\mathrm{P}\left(\mathrm{H}_{2} \mathrm{O}\right)=5 \mathrm{~kb}$. Part II. Melt compositions. J. Petrol. 17, 139-193.

Hollister L. S., Grissom G. C., Peters E. K., Stowell H. H. and Sisson V. B. (1987) Confirmation of the empirical correlation of $\mathrm{Al}$ in hornblende with pressure of solidification of calc-alkaline plutons. Am. Mineral. 72, 231-239.

Irving A. J. and Frey F. A. (1978) Distribution of trace elements between garnet megacrysts and host volcanic liquids of kimberlitic to rhyolitic composition. Geochim. Cosmochim. Acta 42, 771-787.

Jacques D. (1987) Geologie et Petrologie d'archipel Babuyan et des Monts Tabungon et Cagua, Nord Luzon, Philippines: Implications Magmatologiques et Geodynamiques. Unpublished Ph.D. thesis, Université de Bretagne occidentale, France, 393 pp.

Jahn B.-M. (1986) Mid-ocean ridge or marginal basin origin of the East Taiwan Ophiolite: chemical and isotopic evidence. Contrib. Mineral. Petrol. 92, 194-206.

Kay R. W. (1978) Aleutian magnesian andesites: melts from subducted Pacific Ocean crust. J. Volc. Geotherm. Res. 4, 117-132.

Knittel U. and Defant M. J. (1988) Sr isotopic and trace element variations in Oligocene to Recent igneous rocks from the Philippine 
island arc: evidence for Recent enrichment in the sub-Philippine mantle. Earth Planet. Sci. Lett. 87, 87-99.

Knittel U., Defant M. J. and Raczek I. (1988) Recent enrichment in the source region of arc magmas from Luzon island, Philippines: $\mathrm{Sr}$ and Nd isotopic evidence. Geology 16, 73-76.

Knittel U., Trudu A. G., Winter W., Gray C. M. and Steele D. A. (1990) Preliminary petrochemical results from the central segment of the Luzon volcanic arc (Philippines): the Mankayan Mineral District. Proc. Pacific Rim Congr., Vol. 2, pp. 217-223.

Knittel-Weber C. and Knittel U. (1990) Petrology of volcanic rocks on the northeastern flank of Mt Malinao (southern Luzon, Philippines) and a comment on magma genesis in the Bicol arc. J. Southeast Asian Earth Sci. 4, 267-280.

Lambert R. St. J. and Holland J. G. (1974) Yttrium geochemistry applied to petrogenesis utilizing calcium-yttrium relationships in minerals and rocks. Geochim. Cosmochim. Acta 38, 1393-1414.

Lewis S. D. and Hayes D. E. (1984) A geophysical study of the Manila Trench, Luzon, Philippines, 2. Fore arc basin structural and stratigraphic evolution. J. Geophys. Res. 89, 9196-9214.

Lo H. H. (1981) Geochemical investigation of some volcanic rocks from the Philippines. Chem. Geol. 34, 243-257.

Mahlburg Kay S., Maksaev V., Moscosco R., Mpodozis C., Nasi C. and Gordillo C. E. (1988) Tertiary Andean magmatism in Chile and Argentina between $28^{\circ} \mathrm{S}$ and $33^{\circ} \mathrm{S}$ : correlation of magmatic chemistry with changing Benioff zone. J. South Am. Earth Sci. 1, 21-38.

Maleterre P., Stephan J. F., Andreieff P., Bellon H., Chorowicz J., Boirat J. M. and Balce G. R. (1988) The southern Central Cordillera of Luzon: a multistage Upper Eocene to Pleistocene arc deformed on the northern end of the Philippine strike-slip fault. In Symp. Geodynamic Evolution of the Eurasian Margin, Abstracts, p. 81, Paris.

Martin H. (1987) Petrogenesis of Archean trondhjemites, tonalites, and granodiorites from eastern Finland: major and trace element geochemistry. J. Petrol. 28, 921-953.

McDermott F., Defant M. J., Hawkesworth C. J., Maury R. C. and Joron J. L. (1993) Isotope and trace element evidence for three component mixing in the genesis of the North Luzon arc magmas (Philippines). Contrib. Mineral. Petrol. 113, 9-23.

Metal Mining Agency of Japan (1977) Report on Geological Survey of Northeastern Luzon (consolidated report). Unpublished Report.

Metal Mining Agency of Japan (1981) Report on Geological Survey of Northwestern Luzon (consolidated report). Unpublished Report.

Miyashiro A. (1974) Volcanic rock series in island arcs and active continental margins. Am. J. Sci. 264, 321-355.

Nakamura N. (1974) Determination of REE, Ba, $\mathrm{Mg}, \mathrm{Na}$, and $\mathrm{K}$ in carbonaceous and ordinary chondrites. Geochim. Cosmochim. Acta 38, 757-775.

Pautot G. and Rangin C. (1989) Subduction of the South China Sea axial ridge below Luzon (Philippines). Earth Planet. Sci. Lett. 92, $57-69$.

Pautot G., Rangin C., Briais A., Tapponier P., Beuzart P., Lericolais G., Mathieu X., Wu J., Han S., Li H., Lu Y. and Zhao J. (1986) Spreading direction in the central South China Sea. Nature 321, $150-154$.

Peccerillo A. and Taylor S. R. (1976) Geochemistry of Eocene calc-alkaline volcanic rocks from the Kastamonu area, Northern Turkey. Contr. Mineral. Petrol. 58, 63-81.

Philippine Bureau of Mines (1974) Mineral resources of KalingaApayao Province. Report Investigation 73, $20 \mathrm{pp}$.

Pouchou J. L. and Pichoir F. (1984) A new model for quantitative Xray microanalysis. Part I: application to the analysis of homogeneous samples. Rech. Aérospatiale 3, 13-38.
Ramsay W. R. H., Crawford A. J. and Foden J. D. (1984) Field setting, mineralogy, chemistry, and genesis of arc picrites. New Georgia, Solomon Islands. Contrib. Mineral. Petrol. 88, 386-402.

Rapp R. P., Watson E. B. and Miller C. F. (1991) Partial melting of amphibolite/eclogite and the origin of Archean trondhjemites and tonalites. Precambr. Res. 51, 1-25.

Richard M. (1986) Geologie et petrologie d'un jalon de l'arc TaiwanLuzon: L'île de Batan (Philippines). Unpublished Ph.D. thesis. Université de Bretagne occidentale, France, $351 \mathrm{pp}$

Ringenbach J. C. (1992) La Faille Philippine et les chaines en décrochement associés (centre et nord de Luzon). Ph.D. thesis, Université de Nice-Sophia Antipolis, $337 \mathrm{pp}$

Ringenbach J. C., Stephan J. F., Maleterre P. and Bellon H. (1990) Structure and geological history of the Lepanto Cervantes releasing bend on the Abra River Fault, Luzon Central Cordillera, Philippines. Tectonophysics 183, 225-241.

Ringenbach J. C., Pinet N., Stephan J. F. and Deltail J. (1993) Structural variety and tectonic evolution of strike-slip basins related to the Philippine Fault system, northern Luzon, Philippines. Tectonics 12, 187-203.

Rock N. M. S. (1987) The need for standardization of normalized multi-element diagrams in geochemistry: a comment. Geochem. $J$. 21, 75-84.

Shannon J. R. (1979) Igneous petrology, geochemistry, and fission track ages of a portion of the Baguio Mineral District, Northern Luzon, Philippines. Unpublished MSc. thesis, Colorado School of Mines.

Sillitoe R. H. (1983) Enargite-bearing massive sulfide deposits high in porphyry copper systems. Econ. Geol. 78, 348-252.

Sillitoe R. H. and Angeles C. C. Jr (1985) Geological characteristics and evolution of a gold-rich porphyry copper deposit at Guinaoang, Luzon, Philippines. In Asian Mining '85, pp. 15-26. Institute of Mining Metallurgy, London.

Smith D. R. and Leeman W. P. (1987) Petrogenesis of Mount St Helens dacitic magmas. J. Geophys. Res. 92, 10313-10334.

Stephan J. F., Blanchet, R., Rangin C., Pelletier B., Letouzey J. and Muller C. (1986) Geodynamic evolution of the Taiwan-LuzonMindoro belt since the late Eocene. Tectonophysics 125, 245-268.

Taylor B. and Hayes D. E. (1983) Origin and history of the South China Sea Basin. In The Tectonic and Geologic Evolution of Southeast Asian Seas and Islands: Part 2 (Edited by D. E. Hayes), pp. 23-56. American Geophysical Union Monograph 27.

Thomas I. L. and Haukka M. T. (1978) XRF determination of trace and major elements using a single fused disc. Chem. Geol. 21, $39-50$.

Tomblin J. F. (1979) Dacite of the Lesser Antilles. In Trondhjemites, Dacites, and Related Rocks (Edited by F. Barker), pp. 601-628. Developments in Petrology 6, Elsevier, Amsterdam.

Trudu A. G. (1992) The Tirad porphyry copper-gold prospect (Guinaoang, NW Luzon, Philippines), with a special study on tellurian sulfides. Ph.D. thesis, Monash University, Clayton. Australia, $317 \mathrm{pp}$

United Nations (1987) Geology and mineralization in the Baguio area, Northern Luzon. Technical Report no. 5, (DP/UN/PHI-85-00I/5).

Uyeda S. (1982) Subduction zones: an introduction to comparative subductology. Tectonophysics 81, 133-159.

Wolfe J. A. (1981) Philippine geochronology. J. Geol. Soc. Philipp. $35(1), 1-30$.

Yang T.-S., Lee T., Chen C.-H., Cheng S.-N. and Punongbayan R. S. (1992) Aseismic ridge subducted beneath the Luzon arc and its consequences. Acta Geol. Taiwan. 30, 157.162.

Zindler A. and Hart S. (1986) Chemical geodynamics. A. Rev. Earth Planet. Sci. 14, 493-571. 